\title{
Physical and chemical factors influencing species distributions on hydrothermal sulfide edifices of the Juan de Fuca Ridge, northeast Pacific
}

\author{
Jozée Sarrazin ${ }^{1, *}$, S. Kim Juniper ${ }^{2}$, Gary Massoth ${ }^{3}$, Pierre Legendre ${ }^{4}$ \\ ${ }^{1}$ Woods Hole Oceanographic Institution, 360 Woods Hole Road, MS\#8, McLean Lab 201, Woods Hole, \\ Massachusetts 02543, USA \\ ${ }^{2}$ Geotop/University of Québec at Montréal, CP 8888, succ. Centre-Ville, Montréal, Québec H3C 3P8, Canada \\ ${ }^{3}$ Pacific Marine Environmental Laboratory, National Oceanic and Atmospheric Administration, 7600 Sand Point Way NE, \\ Seattle, Washington 98115-0070, USA \\ ${ }^{4}$ Département de Sciences Biologiques, Université de Montréal, CP 6128, succ. Centre-Ville, Montréal, \\ Québec H3C 3J7, Canada
}

\begin{abstract}
This study examines relationships between hydrothermal vent species and their surrounding physical and chemical environment on 2 high-temperature sulfide edifices of the Juan de Fuca Ridge (northeast Pacific). Video imagery and in situ temperature and chemical information were acquired during 2 remotely operated vehicle (ROV) dive programs in 1993 and 1995, for a total of 78 scans. Statistical analyses of environmental and faunal data reveal a heterogeneous distribution (correspondence analyses) of hydrothermal species and demonstrate a significant influence of local physical and chemical conditions on species distnbutions (canonical correspondence analyses). Results confirm the importance of hydrogen sulfide to the distribution of vent species as well as the importance of complex variables such as visible flow intensity and substratum type. Since less than $30 \%$ of the variance in species distribution could be explained by the measured in situ factors, we conclude by stressing the need to evaluate effects of other unmeasured environmental factors such as dissolved oxygen, nitrogen compounds, food availability and biological interactions.
\end{abstract}

KEY WORDS: Hydrothermal vent ecology - Physical and chemical factors . In situ measurements Habitat characterization Species distribution - Sulfide edifice - Statistical analyses - Fluid flow - Substratum types - Mosaic habitat

\section{INTRODUCTION}

The deep-sea hydrothermal vent environment is complex and dynamic, offering organisms a variety of physical habitats from diffuse, low-temperature flows to vigorously venting, high-temperature black smokers (Hannington et al. 1995) (Fig. 1). Redox reactions between reducing hydrothermal solutions and oxygenated seawater provide a rich source of energy for chemolithoautotrophic microbes (Jannasch \& Mottl 1985, Childress et al. 1986, Johnson et al. 1988a, b, Lil-

•E-mail: jsarrazin@whoi.edu ley et al. 1993, Jannasch 1995, Karl 1995). Vent faunal species are thus dependent on vent fluid supply for survival and growth, since these fluids support the primary production of organic matter (Jannasch \& Wirsen 1979, Karl et al. 1980, Jannasch 1995, Karl 1995). At the same time, ambient temperature, fluid flow and chemical conditions can act as abiotic controls on vent community structure. With the exception of limited temperature and/or chemical measurements (Johnson \& Tunnicliffe 1985, Tunnicliffe et al. 1985, Fisher et al. 1988a,b, Johnson et al. 1988a,b, 1994, Chevaldonné et al. 1991, Grehan \& Juniper 1996, Sarrazin et al. 1997. Desbruyères et al. 1998), few studies have been able to relate directly measured in situ physical and chemical 


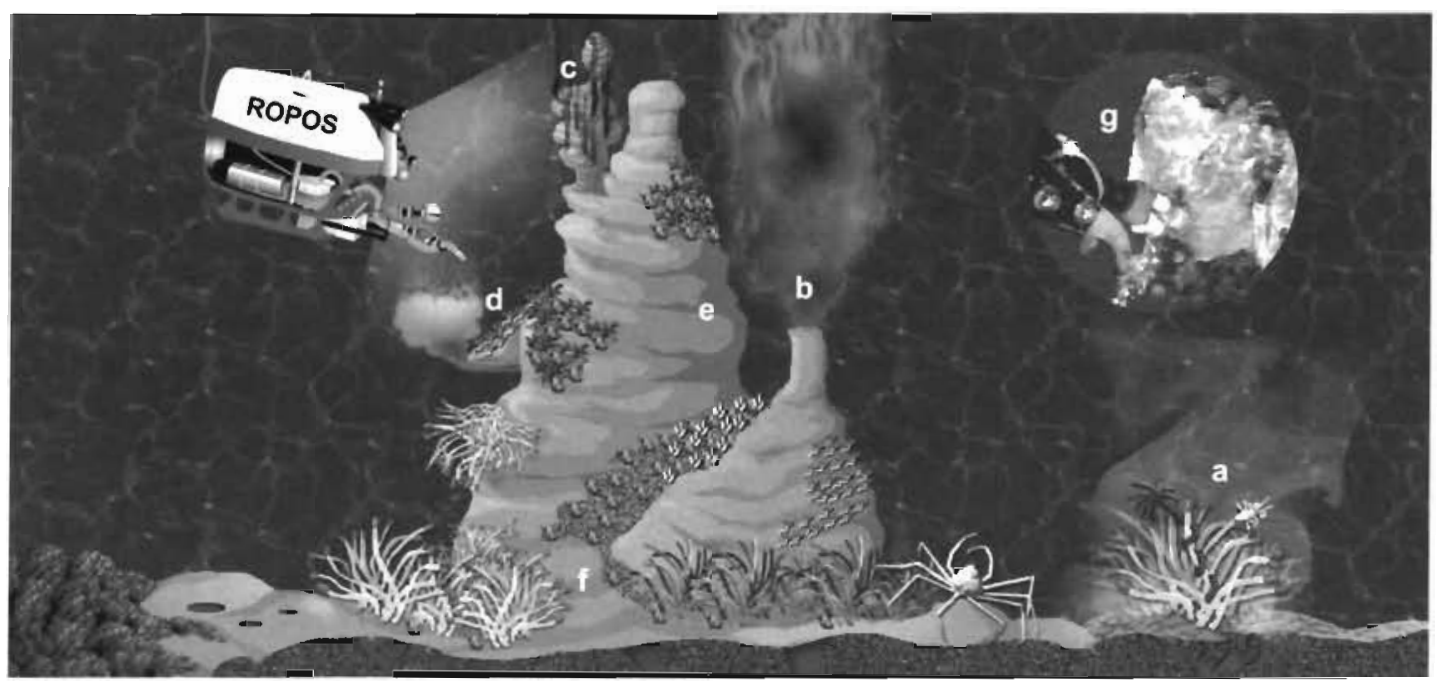

Fig. 1. Artist's (C. Kearney) conception of the hydrothermal sulfide edifice environment on the Juan de Fuca Ridge. Diffuse flow habitats (a) are characterized by extensive mixing, with fluid temperatures generally $<30^{\circ} \mathrm{C}$, whereas black smoker vents (b) discharge hot (up to $400^{\circ} \mathrm{C}$ ), acidic, metal-rich fluids into ambient $\left(2^{\circ} \mathrm{C}\right.$ ) seawater, provoking the precipitation of minerals that will slowly form a sulfide edifice. Edifices up to tens of meters in height harbor dense, heterogeneous faunal communities. Faunal habitat comprises 4 principal types of substrata: beehives (c), flanges (d), vertical walls (e) and edifice base (f). The remotely operated vehicle ROPOS (upper left) was used to study these habitats at depths $>2000 \mathrm{~m}$. (g) Digitized 3-CCD (charge-Coupled device) video image showing the tip of the SUAVE chemical analyzer scanning near the summit of the S\&M (Smoke and Mirrors) edifice. A sulfide worm, Paralvinella sulfincola, is visible near the probe tip on the side of the anhydrite $\left(\mathrm{CaSO}_{4}\right) \mathrm{spire}$

conditions to faunal distribution in order to test proposed links between species and environmental conditions in hydrothermal habitats.

Many authors have suggested links between the physical and chemical properties of vent fluids and the spatio-temporal distribution of hydrothermal species (Desbruyères et al. 1982, 1985, Hessler \& Smithey 1983, Grassle 1985, Hessler et al. 1985, Fustec et al. 1987, Juniper et al. 1990, Tunnicliffe \& Juniper 1990 , Gaill \& Hunt 1991, Tunnicliffe 1991, Segonzac et al. 1993, von Damm 1995, Sarrazin et al. 1997, Tunnicliffe et al. 1997). Faunistic differences between vents and vent sites have been explained by species preferences for particular fluid flow patterns (Tunnicliffe 1991, Sarrazin et al. 1997) for a specific fluid chemical condition (Jones 1985, Tunnicliffe \& Fontaine 1987, Juniper et al. 1990) such as hydrogen sulfide content (Tunnicliffe et al. 1986, Sarrazin et al. 1993) or for a particular temperature range (Fustec et al. 1987, Sarrazin et al. 1997). In other marine benthic environments, substratum characteristics are known to influence larval settlement as well as colonization patterns (Witman \& Cooper 1983, Witman \& Sebens 1988, Dai et al. 1992, Wootton 1993). Despite the presence of several types of substrata in vent habitats, there has been little consideration of their influence on species distribution. Temporal variation in larval supply (Tunnicliffe et al. 1986) and the amount of available particulate organic matter
(Grassle 1985) may also affect faunal composition at vents, as may the size, age, vigor and depth of a vent field (Southward et al. 1997).

The physical and chemical characteristics of vent emissions are initially the result of complex rock-water interactions in the subsurface that form high-temperature 'primary' hydrothermal fluids. These fluids can be subsequently modified by subseafloor and near-surface mixing with background seawater (Butterfield \& Massoth 1994), mineralization processes (Haymon \& Kastner 1981, Koski et al. 1994) and biological activity (Juniper et al. 1988, Juniper 1994, Juniper \& Martineu 1995, Juniper \& Sarrazin 1995, Tivey 1995). Consequently, individual vents vary substantially in water temperature $\left(\sim 2\right.$ to $\left.400^{\circ} \mathrm{C}\right), \mathrm{H}_{2} \mathrm{~S}(\sim 1 \mu \mathrm{M}$ to $18 \mathrm{mM})$ and metal concentrations (Karl 1985, von Damm 1995), as well as $\mathrm{pH}$, chlorinity, $\mathrm{CO}_{2}, \mathrm{CH}_{4}, \mathrm{H}_{2}$ and $\mathrm{Si}$ (Massoth et al. 1989, Butterfield et al. 1990, 1994). Within this milieu of steep physical and chemical gradients, it remains difficult to precisely define conditions favoring individual species, since all habitat information must be collected remotely by submersibles. The recent development of analytical tools such as submersible chemical analyzers (Johnson 1986a,b, Massoth et al. 1989) and flow rate samplers (Schultz et al. 1992) permit in situ characterization of vent habitat conditions. Preliminary interpretation of chemical and biological data from a sulfide edifice on the Juan de 
Fuca Ridge (Sarrazin et al. 1993) suggested that some hydrothermal species occur within definable physical and chemical niches.

This study represents one of the first extensive applications of in situ physical and chemical measurements to the question of environmental control of species distribution at hydrothermal vents. The submersible chemical analyzer System Used to Assess Vented Emissions (SUAVE) (Massoth et al. 1989) was used on 2 separate, active sulfide edifices on the Juan de Fuca Ridge to characterize the habitat surrounding 9 to 11 megafaunal species or groups. Substratum type and fluid flow intensity were also determined from video imagery. These sulfide structures are typical of hydrothermal sites where substantial mineral deposition is occurring. They can be up to tens of meters high and are characterized by multiple orifices, complex overgrowths, and frequent break-outs through chimney walls (Tivey \& Delaney 1986, Hannington et al. 1995). Species distributions and relationships between species and environmental factors within each site were determined statistically, using correspondence and canonical correspondence analysis respectively.

\section{MATERIALS AND METHODS}

Study site. The 2 study sites (Fountain and S\&M [Smoke and Mirrors] edifices) are located on separate segments of the Juan de Fuca Ridge (Fig. 2). The first structure, Fountain, was sampled in 1993 (Vents '93 cruise), while the second, S\&M, was sampled in 1995 (RopoBios ' 95 cruise). Both missions used the remotely operated vehicle (ROV) 'ROPOS' that was deployed from the NOAA ship 'Discoverer' (1993) and the CSS 'John P. Tully' (1995).

Fountain vent was first discovered in 1990 on the $70 \mathrm{~km}$ long Cleft Segment at the base of an east-facing slope (Butterfield \& Massoth 1994, Koski et al. 1994) (Fig. 2). This active, 2-lobed sulfide structure, 3 to $4 \mathrm{~m}$ in height and $5 \mathrm{~m}$ in diameter (Koski et al. 1994), is located near $44^{\circ} 39^{\prime} \mathrm{N}, 130^{\circ} 15^{\prime} \mathrm{W}$ at a depth of approximately $2270 \mathrm{~m}$. In 1991, particle-rich fluid was venting through several small beehive chimneys and approximately 6 high-temperature orifices $\left(275\right.$ to $\left.310^{\circ} \mathrm{C}\right)$ near the top of the edifice; several areas of diffuse flow were also observed (Butterfield \& Massoth 1994).

The S\&M edifice is an actively venting structure located near the center of the Main Endeavour Field on the Endeavour segment (Fig. 2). It is located near $47^{\circ} 57^{\prime} \mathrm{N}, 129^{\circ} 08^{\prime} \mathrm{W}$, at a depth of $\sim 2200 \mathrm{~m}$ (Tivey \& Delaney 1986). It is a complex, $11 \mathrm{~m}$ high structure, elongated parallel to the north-south trend $\left(020^{\circ}\right)$ of the axial valley (Delaney et al. 1992). S\&M has been the site of detailed geological and biological studies
(Delaney et al. 1992, Thomson et al. 1992, Robigou et al. 1993, Sarrazin et al. 1997, Sarrazin \& Juniper 1999) as well as hydrothermal fluid sampling (Butterfield et al. 1994). Venting temperatures measured on black smoker fluids at S\&M over the year range from 329 to $369^{\circ} \mathrm{C}$ (Butterfield et al. 1994). The morphology of this sulfide edifice differs from the typical Endeavour-type structure, probably indicating that $S \& M$ is at a young stage of activity (Sarrazin et al. 1997).

In situ chemical analyses. Determinations of dissolved $\mathrm{H}_{2} \mathrm{~S}$ (methylene blue method, Sakamoto-Arnold et al. 1986), Fe (II + III; ferrozine method, Chin et al. 1994) and Mn (II: PAN method, Chin et al. 1992) were made in situ by the SUAVE chemical analyzer (Massoth et al. 1991). SUAVE is a second-generation submersible chemical analyzer (after Johnson et al. 1986a), and is based on the principles of flow injection analysis and colorimetric detection. SUAVE components were fitted into a specially designed rack within the ROPOS frame. The sampling probe was fixed to the ROPOS 7 -function manipulator arm for precise positioning using real-time video imagery.

In 1993, 32 SUAVE scans were acquired among different species assemblages that colonized the Fountain edifice. In 1995, 46 scans were collected on the S\&M structure. For each scan, the tip of the sampling probe

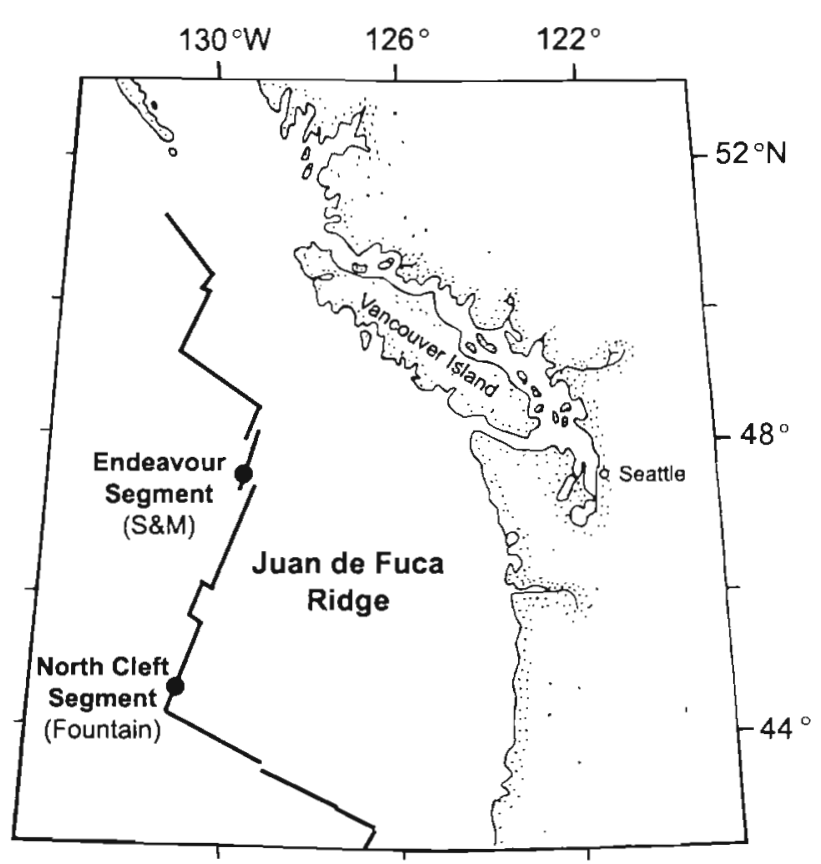

Fig. 2. General location map of the Endeavour and North Cleft Segments, Juan de Fuca Ridge, nor theast Pacific Ocean. The S\&M sulfide structure $\left(47^{\circ} 57^{\prime} \mathrm{N}, 129^{\circ} 08^{\prime} \mathrm{W}\right)$ is located on the edge of a fault scarp in the center of the Main Endeavour hydrothermal vent field. The Fountain edifice is located at the base of an east-facing slope $\left(44^{\circ} 39^{\prime} \mathrm{N}, 130^{\circ} 15^{\prime} \mathrm{W}\right)$ 
was placed in the middle of a clump of animals (see Fig 1g) and, when the submersible was stable, fluid was pumped for approximately $5 \mathrm{~min}$. The fluid stream was propelled continuously by a peristaltic pump through a $10 \mu \mathrm{m}$ intake filter and $3 \mathrm{~m}$ of tubing to a mixing manifold where it was split and merged with reagents to form specific colored reaction products whose light attenuation was measured at $5 \mathrm{~s}$ intervals while passing through an LED-photodiode detector. A series of pinch valves allowed injection of standards into the flowstream to produce in situ standardizations.

Chemical data were monitored on ship via a fibreoptic link to the ROPOS vehicle. Residence time in the SUAVE flow system resulted in a 4 to 9 min delay between entry at the probe tip and signal detection at the LED-photodiode detector. Probe tip temperature was monitored in real-time with no delay. Thermal and chemical data were later reconciled to compensate for offsets in the chemical signal. The response time at the detector (i.e. smearing induced by the flow system of an instantaneous change in concentration) was approximately $45 \mathrm{~s}$. Individual SUAVE 'scans' were in fact a temporal series of temperature and chemical data from fixed locations. They began when the scanner tip was stably placed in the selected location, and ended $5 \mathrm{~min}$ later. Some scans were shortened by loss of vehicle stability. Scan duration varied around a mean of $4.8 \mathrm{~min}$ (SD 1.6).

In order to characterize average conditions experienced by organisms at the time scale of the scans, we developed an objective protocol for data selection. The first data point was defined by the first temperature peak following the beginning of the scan. Where possible, chemical and temperature data were compiled for 5 min following this temperature peak, or until the end of the scan. Mean, maximum and minimum values were determined for measured data from each scan.

Faunal assemblage characteristics. Video frames documenting each scan were digitized and analyzed individually to determine organism abundance and density, as well as species richness (see method in Sarrazin \& Juniper 1998) for visible mega/macrofaunal species. The studied fauna is dominated by the species and faunal groups listed in Table 1a. Species identified only to the level of faunal groups were impossible to distinguish from one another on video imagery. These include polynoid polychaetes (POLY), pycnogonids (PYCN) and gastropods (GAST). Nevertheless, some species within these groups were considered separately. Lepidonotopodium piscesae (LEPI) can be easily differentiated from other polynoids because it is often covered by a white bacterial layer (Pettibone 1988). The gastropod Buccinum of viridum (BUCC) was easily differentiated from other gastropods because of its large size and distinct color. Groupings of the vestimentiferan Ridgeia piscesae were classed as senescent (SENR) when the majority of tubes showed no branchial plumes after several minutes of observation in video imagery (Sarrazin \& Juniper 1999). Highly mobile predators and scavengers (MOBI) were also included in our study. $\mathrm{H}$-shaped PVC markers as well as a chain were deployed at Fountain to scale video imagery. Parallel laser beams were available in 1995 to scale the video images. Where laser scales and markers were absent (1993 and some 1995 images), submersible tools (scanner probe, manipulator claws, etc.) were used for scaling.

Once scale was established on the frames, faunal data were acquired within areas centered on the probe tip by overlaying electronically generated circles on the digitized video images. Decimeter-scale spatial variability in environmental conditions and organism distribution appears to be common on sulfide edifices (Tunnicliffe 1991, Sarrazin et al. 1997) whereas the fauna was generally similar at the centimeter scale around the scan points. Accordingly, $5 \mathrm{~cm}$ diameter circles were used to estimate relative organism densities (number of individuals $\mathrm{m}^{-2}$ ) and species richness (number of species). Species presence or absence in the whole video frame was also reported. This analysis considered the entire visible area around the probe tip where similar visible conditions (substratum, faunal assemblages, visible flow) were observed. This was done principally to include mobile species in our study, many of which moved away when disturbed, and to include uncountable species such as filamentous bacteria. We considered 9 species or faunal groups for abundance, density and richness analyses, and 11 were included in the presence-absence database.

Faunal abundance and composition evaluated from video imagery did not account for organisms obscured by thick tube worm overgrowths or those not visible to the naked eye (macro/meiofauna). For some scans, poor image quality may have resulted in underestimation of organism abundance.

Substratum and flow characteristics. A series of quantitative and qualitative data was assigned to each scan location. Substratum and visible flow types were classified into 4 categories (see Table $1 b, c$ ). Substratum types include the edifice base as well as vertical walls, flanges and beehives. Flow types were classified by a quantitative fluid intensity index. They were scaled from 'no visible flow' (0) to 'indirect black smoke' (1.5). To evaluate how these factors related to measured environmental factors, they were compared against temperature and chemical data.

Statistical analyses. Relationships between maximum and mean values for temperature and chemical data were examined in simple linear regressions. Linear regressions were also computed between environmental factors. 
Correspondence analysis (CA) (Canoco program, ter Braak 1988, 1990) was used to identify patterns of faunal distribution (presence-absence and relative organism abundance) among scans on the 2 sulfide structures. This was repeated with pooled data from both structures. Since more variance in species data was explained by considering the structures separately than by analyses of pooled data, pooled data were not considered further.

Discriminant analysis was used to determine if the global physical and chemical properties of the 2 sites, as well as those of the different substratum types, were similar or different. This type of analysis is often used to identify which variables are useful to discriminate between 2 or more naturally occurring groups (Legendre \& Legendre 1998).

Canonical correspondence analyses (CCA) were performed to evaluate the links between environmen- tal conditions and faunal observations (ter Braak 1986. $1987 \mathrm{a}$ ). The aim of the canonical ordinations was to detect patterns of variation in species data that could be best explained by linear combinations of the observed environmental variables (ter Braak 1987a, Legendre \& Legendre 1998). Canonical ordination combines aspects of regular ordination analysis and multiple linear regression, selecting the linear combination of environmental variables that maximizes the dispersion of species scores. The resulting ordination diagram expresses not only a pattern of variation in species composition but also the main relationships between the species and the environmental variables. The canonical eigenvalues measure how much of the variation in the species data is explained by the axes and, hence, by the environmental variables (ter Braak 1987b).

The multistate qualitative descriptors of substratum type and visible flow intensity were binary-coded as

Table 1 Percentage of scans: (a) that included different species or faunal groups, (b) on different substrata as well as on bare versus colonized surfaces, and (c) for each level of visible fluid flow

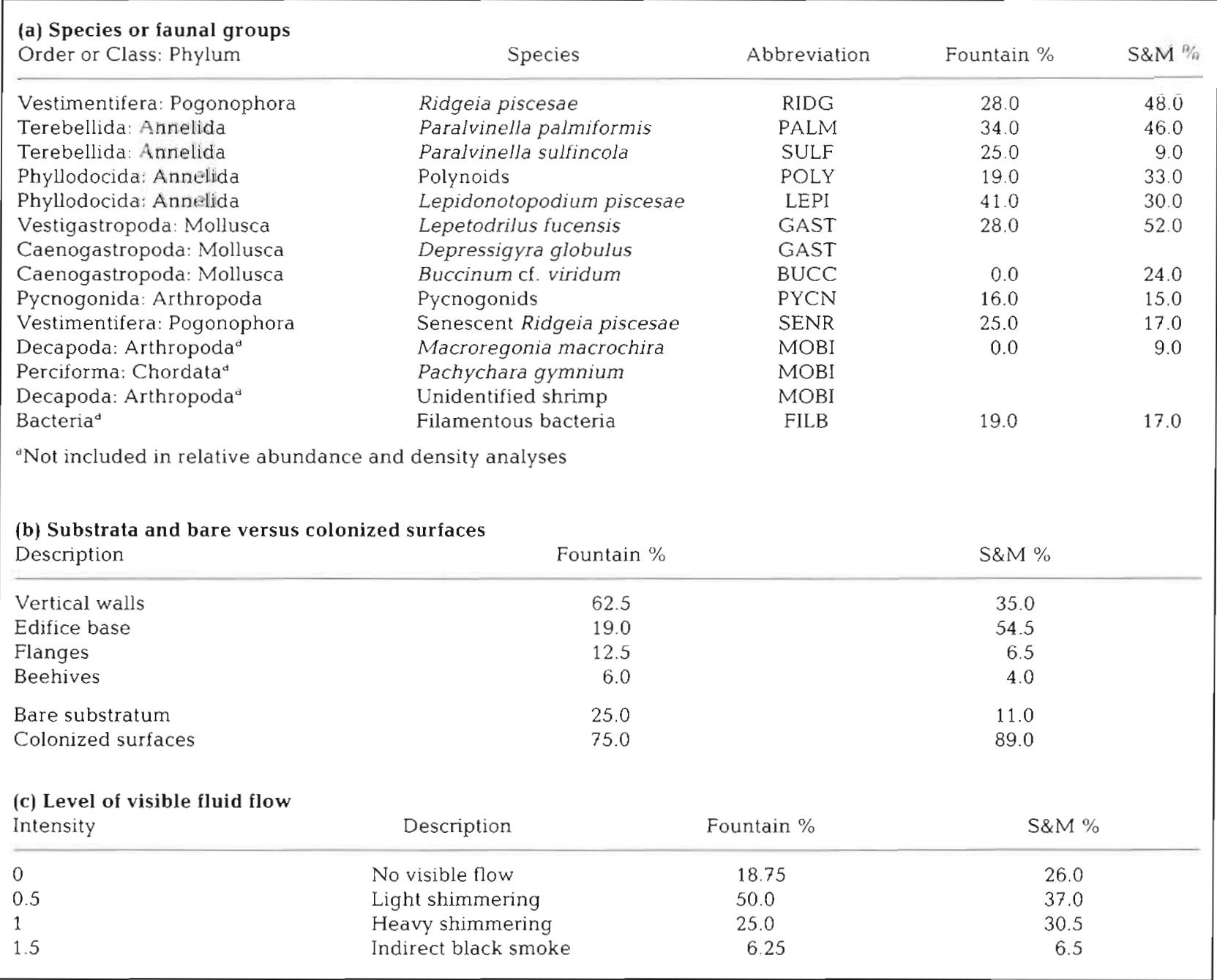


'dummy variables' for statistical analyses (Legendre \& Legendre 1998). To examine the influence of shortterm temporal variability of measured physical and chemical factors on species distributions, we used coefficients of variation (CV) for measured temperature and chemical concentrations ([standard deviation/ mean] $\times 100$ ).

No data transformation or normalization was performed prior to statistical analyses (discriminant, $C A$, CCA). A probability ( $p$ ) value of $\leq 0.05$ was considered as the limit of significance for all statistical analyses. Nevertheless, a 'border-line' value of $\mathrm{p} \leq 0.1$ was considered sufficient for noting trends.

Data corrections. For 1 dive on S\&M (1995), only manually noted maximum concentration and temperature values were available $(n=15)$. Mean chemical concentrations and temperature were interpolated from linear regressions of mean on maximum values from all other scans on $S \& M\left(R^{2} \geq 0.98, p \leq 0.01\right)$.

Physical and chemical niche determination. The species presence-absence and SUAVE (temperature, $\mathrm{Fe}^{2+}, \mathrm{Mn}^{2+}$ and $\mathrm{H}_{2} \mathrm{~S}$ ) databases for the 2 sites were combined to develop indices of the average and the range of habitat conditions experienced by individual species or faunal groups. Mean habitat temperature, $\mathrm{Fe}^{2+}, \mathrm{Mn}^{2+}$ and $\mathrm{H}_{2} \mathrm{~S}$ data for each species (or group) were normalized to the highest value $\left(x / x_{\max }\right)$. For example, for the species Ridgeia piscesae (RIDG) on $\mathrm{S} \& \mathrm{M}$, the mean habitat temperature $\left(8.96^{\circ} \mathrm{C}\right)$ for all the locations where this species was present was normalized to the highest habitat temperature measured for this structure $\left(16.71^{\circ} \mathrm{C}\right.$ for Paralvinella sulfincola, SULF). The same was done for $\mathrm{Fe}^{2+}, \mathrm{Mn}^{2+}$ and $\mathrm{H}_{2} \mathrm{~S}$. The 4 indices were summed to give the index of mean habitat condition for $R$. piscesae on both S\&M and Fountain. The procedure was repeated for all species (or groups). In the same way, habitat breadth index was calculated from the normalized range data determined from minimum and maximum chemical concentrations or temperatures, for each species, on the 2 sulfide structures. Mean habitat condition and habitat breadth indices were then plotted against each other.

\section{RESULTS}

\section{Data characteristics}

Spatio-temporal variability of physical and chemical factors

Considerable short-term temporal variability of measured factors was observed during individual scans. Scans fell into 2 major categories: those with a pro- nounced single peak and low CV and those with multiple peaks and a high CV (Fig. 3). This variability can be attributed to natural vent flow fluctuation, submersible turbulence, and/or bottom currents. CCA showed that faunal distribution was not influenced by the observed short-term variability of physical and chemical factors on Fountain. On S\&M, temporal variations in $\mathrm{H}_{2} \mathrm{~S}$ and $\mathrm{Mn}^{2+}$ explained $16.9 \%$ of the variance of species distribution.

We occasionally observed substantial small-scale spatial variability of environmental factors, although no systematic spatial study was incorporated into the field programs. For example, for 2 scans spaced by $8 \mathrm{~cm}$, taken on adjacent colonized and uncolonized surfaces of the S\&M structure, we observed that chemical concentrations and temperature varied by factors of 2.8 to 9.4 . Temperature was $6.9^{\circ} \mathrm{C}$ on the colonized area, and over $40^{\circ} \mathrm{C}$ on the uncolonized surface.

\section{Correlations between environmental factors}

Most measured environmental factors were significantly correlated with one another $(p \leq 0.05)$. Temperature positively correlated with almost all factors $\left(\mathrm{R}^{2} \geq\right.$ 0.62, $\mathrm{p}<0.01$ ). Similarly, the visible flow index (see Table 1c) was positively correlated with all measured factors $\left(R^{2} \geq 0.38, p<0.05\right)$ except manganese $\left(R^{2} \leq\right.$ $0.28, p>0.05$ ). Calibrated visible flow could serve as an interesting tool to predict the physical and chemical properties of unmeasured areas.

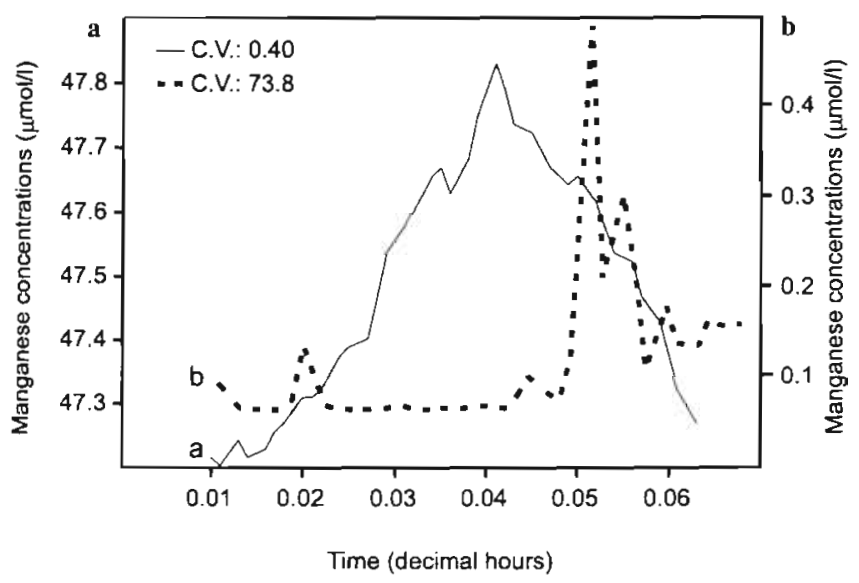

Fig. 3. Contrasting variance properties in scan data, as illustrated by dissolved manganese concentrations. Scans fell into 2 major categories: (a) those with a pronounced single peak and a low coefficient of variation (CV), and (b) those with multiple peaks and a high $C V$. Data from: (a) Fourtain and (b) $S \& M$ 
Representation of faunal and habitat features in scans

We identified 11 faunal groups in the scans (Table 1a). All were present in the S\&M scans while no Buccinum cf viridum snails or mobile species were observed in Fountain scans. Choice of scan locations on both edifices was influenced by accessibility. All 4 types of substrata were represented in different proportions among the scans of both structures (Table 1b). The large majority of Fountain scans were done on vertical walls, while on S\&M they were on edifice base. Overall, a larger percentage of scans were performed on colonized surfaces (>75\%). On S\&M, scans were almost equally distributed among the different levels of visible flow, while on Fountain the large majority was done in areas of light shimmering flow (Table $1 \mathrm{c}$ ).

\section{Habitat and faunal characteristics}

\section{Comparison of sites}

Overall, Fountain scan points tended to have fewer species and individuals (estimated from $19.64 \mathrm{~cm}^{2}$ areas) than scans on S\&M. A discriminant analysis using total organism density and species richness showed a significant difference between the 2 sites $(\mathrm{p}<0.002)$. The most discriminating variable was total density $(p<0.01)$, which was almost 2 times higher on S\&M (5246 \pm 4625$)$ than on Fountain (2136 \pm 2317$)$.

There were clear differences in the physical and chemical characteristics of scans between the 2 sites, as confirmed by a discriminant analysis ( $p<0.0001$ ) which identified $\mathrm{H}_{2} \mathrm{~S}$ ( $\mathrm{p}=0.002$; higher on $\left.\mathrm{S} \& M\right)$ and $\mathrm{Mn}^{2+}(\mathrm{p}=0.0001$; higher on Fountain) as the most discriminating variables (Table 2 ).

\section{Comparison of substrata}

For Fountain, despite observation of higher total organism abundance and density on vertical walls (Table 3) and greater species richness on flanges, a discriminant analysis showed no significant differences in the faunal data among the 4 types of substratum on this structure $(p>0.05)$. On S\&M, total species richness as well as organism abundance and density were highest at edifice base. A discriminant analysis showed that faunal data were significantly different among the 4 substrata $(p<0.02)$. Species richness was the most discriminating faunal variable $(p=0.02)$.

Overall, values for temperature as well as visible flow increased from the base of the structures through vertical walls, overhangs and beehives occurring on the edifice itself (Fig. 4). Fountain vertical walls tended
Table 2. Mean measured environmental factors ( $\pm \mathrm{SD}$ ) for the 2 sulfide structures (Fountain and S\&M). Concentrations are in $\mu \mathrm{mol} \mathrm{I}^{-1}$ and temperature in ${ }^{\circ} \mathrm{C}$. Discriminant analyses showed that hydrogen sulfide and manganese concentrations were the most discriminating variables between the 2 structures $(\cdots p<0.001, \cdots p<0.01)$

\begin{tabular}{|lcc|}
\hline $\begin{array}{l}\text { Environmental } \\
\text { factors }\end{array}$ & $\begin{array}{c}\text { Fountain } \\
(\mathrm{n}=32)\end{array}$ & $\begin{array}{c}\mathrm{S} \& \mathrm{M} \\
(\mathrm{n}=41)\end{array}$ \\
\hline Temperature & $5.82 \pm 5.0$ & $7.52 \pm 8.8$ \\
$\mathrm{H}_{2} \mathrm{~S} \cdots$ & $22.17 \pm 37.8$ & $38.32 \pm 47.2$ \\
$\mathrm{Mn} \cdots$ & $12.16 \pm 10.8$ & $0.51 \pm 1.6$ \\
$\mathrm{Fe}$ & $6.54 \pm 13.8$ & $10.84 \pm 16.2$ \\
\hline
\end{tabular}

Table 3. Mean total organism density and abundance as well as species richness (estimated on $5 \mathrm{~cm}$ diameter areas) for the different substratum types. Discriminant analyses showed that species richness was the most discriminating variable between the 4 substrata, and this only on S\&M $(\cdot p<0.05\}$

\begin{tabular}{|lrccc|}
$\begin{array}{l}\text { Substratum } \\
\text { type }\end{array}$ & $n$ & $\begin{array}{c}\text { Total } \\
\text { abundance }\end{array}$ & $\begin{array}{c}\text { Total density } \\
\text { (ind. } \mathrm{m}^{-2} \text { ) }\end{array}$ & Richness \\
\cline { 1 - 2 } $\begin{array}{l}\text { Fountain } \\
\text { Edifice base }\end{array}$ & 6 & 2.8 & 1446 & 1.0 \\
Vertical walls & 20 & 4.9 & 2500 & 1.1 \\
Flanges & 4 & 3.8 & 1913 & 1.3 \\
Beehives & 2 & 2.0 & 1020 & 0.5 \\
S\&M & & & & \\
Edifice base & 25 & 11.2 & 5735 & $2.0^{\circ}$ \\
Vertical walls & 16 & 10.8 & 5517 & $1.4^{\circ}$ \\
Flanges & 3 & 3.3 & 1701 & $1.0^{\circ}$ \\
Beehives & 2 & 4.5 & 2296 & $0.5^{\circ}$ \\
& & & & \\
\hline
\end{tabular}

to have higher concentrations of dissolved chemical species than other substrata (Fig. 4). A discriminant analysis showed a significant difference between the physical and chemical characteristics of the 4 types of substratum located on this structure $(p<0.05)$. Temperature ( $p=0.03)$ was the most discriminating variable along with $\mathrm{H}_{2} \mathrm{~S}(\mathrm{p}=0.07)$. On $\mathrm{S} \& \mathrm{M}$ the trend was different. Manganese concentrations were highest at edifice base whereas hydrogen sulfide and iron concentrations peaked on beehives. Temperature was also highest on beehives, which are morphological features that often cap high temperature black smokers (Koski et al. 1994). Differences in SUAVE data between the 4 types of substratum were significant $(\mathrm{p}<0.01)$ as shown by a discriminant analysis. $\mathrm{H}_{2} \mathrm{~S}$ and $\mathrm{Mn}^{2+}(\mathrm{p}<$ 0.07 ) best explained the chemical differences between substrata on S\&M.

\section{Faunal distribution}

Overall, species were not homogeneously distributed among the scans. Certain species tended to have 

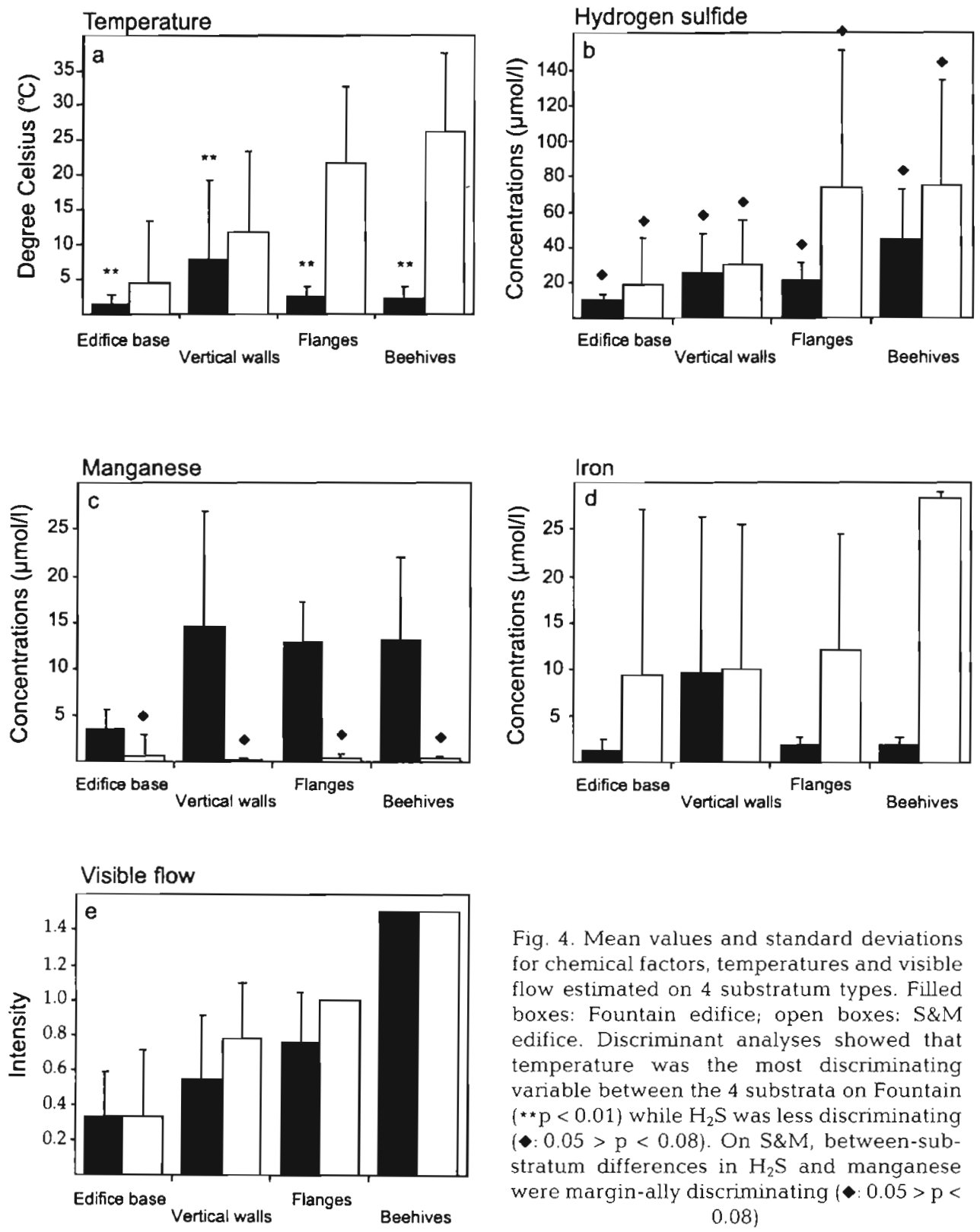

Fig. 4. Mean values and standard deviations for chemical factors, temperatures and visible flow estimated on 4 substratum types. Filled boxes: Fountain edifice; open boxes: S\&M edifice. Discriminant analyses showed that temperature was the most discriminating variable between the 4 substrata on Fountain (** $\mathrm{p}<0.01$ ) while $\mathrm{H}_{2} \mathrm{~S}$ was less discriminating $(\bullet: 0.05>p<0.08$ ). On S\&M, between-substratum differences in $\mathrm{H}_{2} \mathrm{~S}$ and manganese were margin-ally discriminating $(\bullet 0.05>\mathrm{p}<$ 0.08 )

distinct distribution patterns (co-occurrence, opposite distributions, etc.), and some trends were common to both structures. In separate CA of faunal distribution in Fountain and S\&M scans, a high percentage ( $>75 \%$ ) of total variance was explained by the 4 ordination axes (Fig. 5, only 2 axes are shown). For both presenceabsence and relative abundance senescent Ridgeia piscesae (SENR) and Paralvinella sulfincola (SULF) tended to separate from other species, particularly on Fountain. Filamentous bacteria (FILB) also tended to pool apart. R. piscesae (RIDG), gastropods (GAST) and Paralvinella palmiformis (PALM) tended to group together.

SUAVE scan points, as defined by faunal data, showed a slight trend in relation to their relative positions on the 2 structures, with scan locations at the edifice bases grouping separately from points on the walls and summits (CA not shown). This trend was most evident for S\&M. Examination of corresponding faunal and scan ordinations permits further interpretation. For example, senescent Ridgeia piscesae that grouped apart from other species can be associated with scans from the edifice base. Similarly, Paralvinella sulfincola was uniquely associated with scans from the walls and summits. Other species were represented in scans from all areas of the edifice. 


\section{Species-habitat relationships}

Faunal-habitat relationships were examined using CCA. Resulting canonical ordinations of species points and environmental variable arrows are actually biplots that approximate the weighted averages of each species with respect to each environmental variable (Figs. $6 \&$ 7). Quantitative (temperature, $\mathrm{H}_{2} \mathrm{~S}, \mathrm{Mn}^{2+}$ and $\mathrm{Fe}^{2+}$ ) and semi-quantitative (visible flow) environmental variables can be interpreted in conjunction with the species points as follows: each environmental variable, represented by an arrow, determines an axis in the diagrami the species points are projected onto this axis to indicate the positions of the modes of the species distribution curves with respect to the given environmental variable (e.g Fig. 6C).

Species with a high positive score on an axis that correlates with an environmental variable are abundant in areas with high values of this variable, whereas species with a large negative score mainly occur in areas with low values of this environmental factor. Species with intermediate scores are either unaffected by the factor or associated mostly with intermediate values (ter Braak 1987b). Classes of nominal environmental. variables (substrata) are represented by a point at the centroid (the weighted average) of the sites (scans)

\section{Presence-absence}
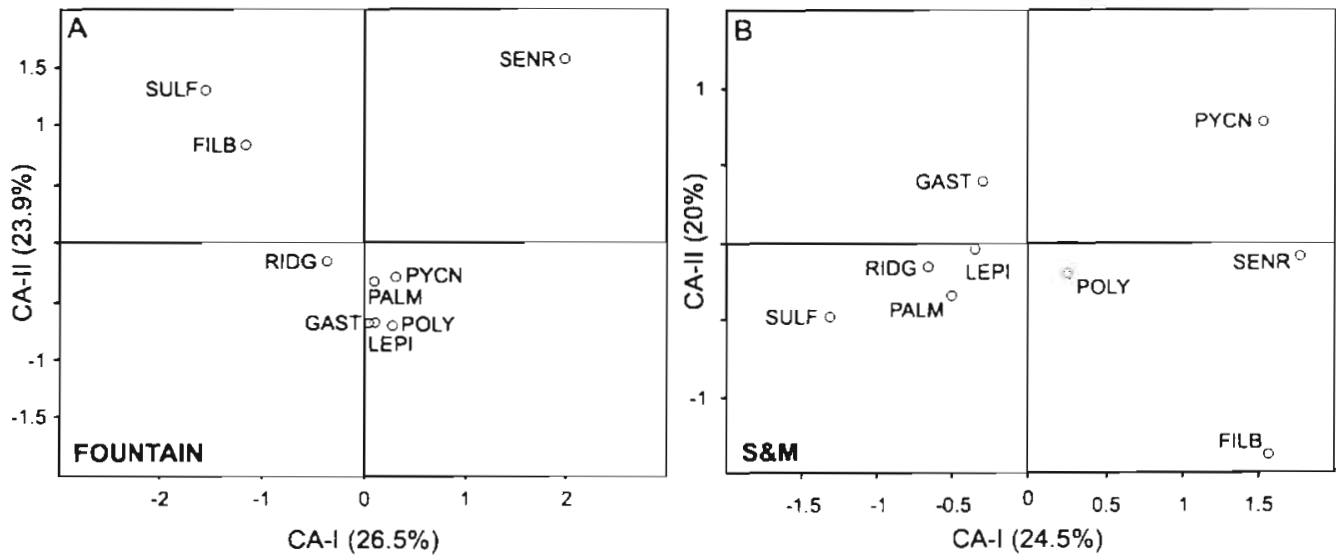

Relative abundance
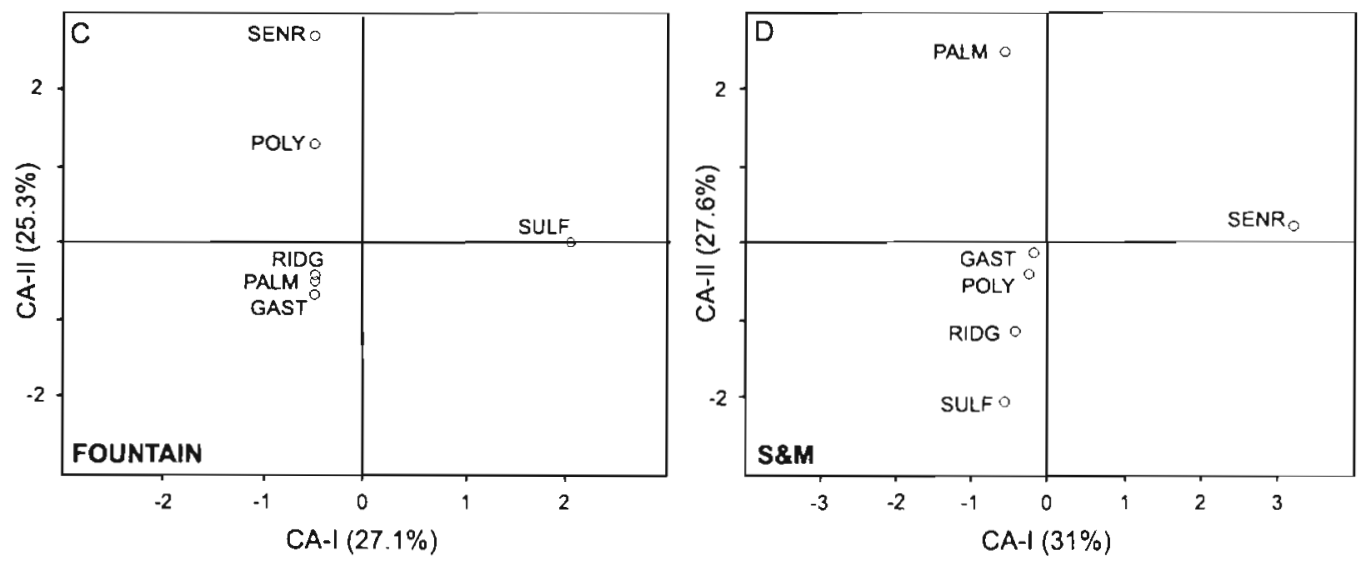

Fig. 5. Ordination diagram for correspondence analysis (CA) of species data and related scan points on both sulfide structures. First 2 axes show the distribution of species relative to each other among SUAVE scans on both sulfide edifices. Corresponding dispersion of scans according to species distribution is not illustrated. (A) Species presence-absence dispersion on Fountain. All 4 axes account together for $75.3 \%$ of the dispersion in the species data $(26.5,23.9,13.3$ and $11.6 \%$ respectively). (B) Species presence-absence dispersion on S\&M. All 4 axes account together for $76.9 \%$ of the dispersion in the species data (24.5, 20, 17 and $15.4 \%$ respectively). (C) Relative organism abundance dispersion on Fountain. All 4 axes account together for $90.1 \%$ of the dispersion in the species data $(27.1,25.3,22.1$ and $15.6 \%$ respectively). (D) Relative organism abundance dispersion on S\&M. All 4 axes account together for $95.5 \%$ of the dispersion in the species data $(31,27.6,24.3$ and $12.6 \%$ respectively). Individual axes do not represent specific environmental factors but rather are products of the CA. See Fig. 6 for abbreviations 

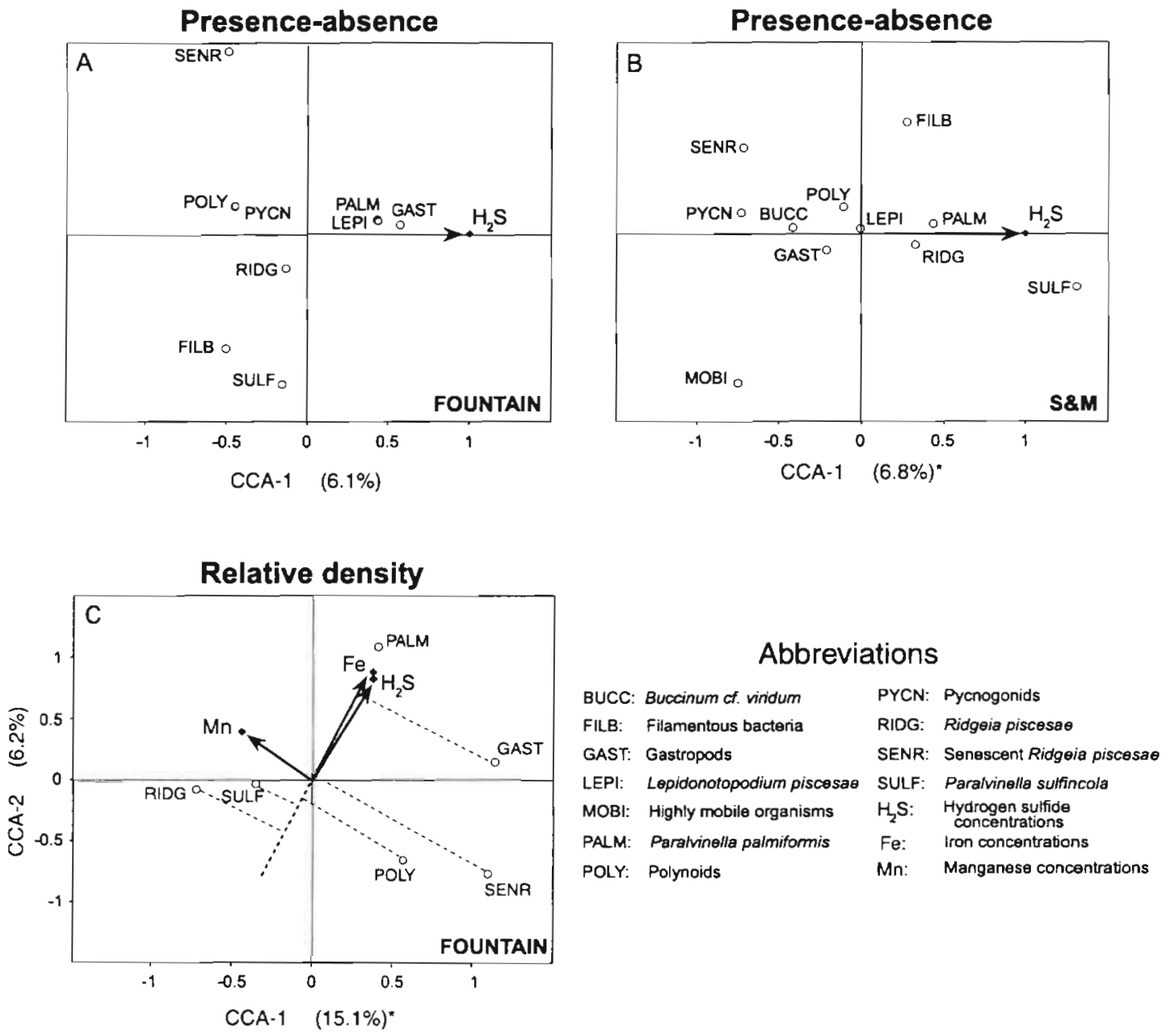

Fig. 6. Ordination diagram for canonical correspondence analysis (CCA) of temperature and chemical factors (independent variables) against species data (dependent variables). ( $\bullet$ ) Environmental variables. (A) Species presence-absence dispersion related to temperature and chemistry on Fountain. The first canonical axis accounted for $6.1 \%$ of the dispersion in the species data. Only 1 canonical axis was found. The overall canonical species-environment relationship was significant $(p=0.05)$. (B) Species presence-absence dispersion related to temperature and chemistry on S\&M. First canonical axis accounted for $6.8 \%$ of the dispersion in the species data. Only 1 canonical axis was found. The overall canonical species-environment relationship was significant $(p=$ 0.002). (C) Relative organism densities related to temperature and chemistry on Fountain. The first 3 canonical axes accounted together for $23.9 \%$ of the dispersion in the species data. Axis I: $15.1 \%$ of the variation ( $\mathrm{p}=0.026$ after 999 permutations); axis II: $6.2 \%$ of the variation ( $p=0.392$ after 999 permutations). The overall test of significance was only significant for the first axis $(p=$ 0.011 ). An example of projection of species positions onto axes defining significant factors is shown (C) for $\mathrm{H}_{2} \mathrm{~S}$. No measured factors were significantly affecting organism densities on S\&M. Abbreviations for Figs. 5, 6, $7 \& 8$ are listed here

belonging to that class (see Fig. 7). Species with high affinity for a particular substratum are then positioned close to the point representing that substratum.

\section{Effect of temperature and chemistry on species distribution}

Overall, CCA showed that species presence-absence, as well as organism relative densities was influenced by physical and chemical factors on the 2 sulfide edifices. On Fountain, hydrogen sulfide, manganese and iron concentrations were affecting species distributions (Fig. 6A,C) whereas on S\&M hydrogen sulfide concentrations were significantly influencing species presence-absence (Fig. 6B). The position of iron in the Fountain CCA ordination (Fig. 6C) is similar to that of hydrogen sulfide, so the species associated with high hydrogen sulfide concentrations were also associated with high iron values, and vice versa. Overall, measured physical and chemical factors explained only a low percentage of the variance in the species data ( $6 \%$ for species presence-absence on both structures, and $-15 \%$ for organism relative densities on Fountain). 

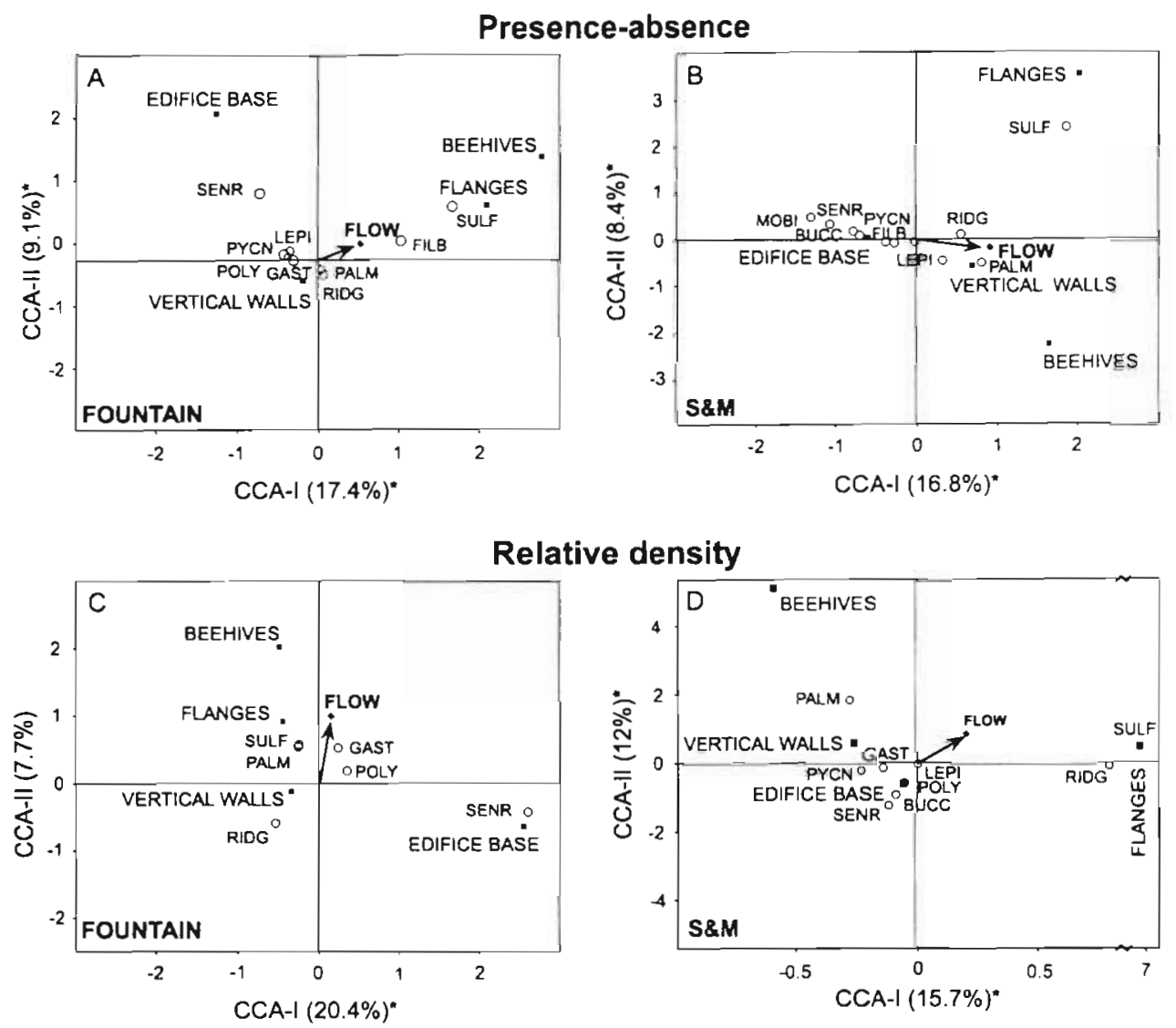

Fig. 7. Ordination diagram for canonical correspondence analysis (CCA) of substratum types and visible flow (independent variables) against species data (dependent variables). (ロ) Substratum classes ( $^{*}$ ) and visible flow. (A) Species presence-absence dispersion related to substratum and flow on Fountain. The first 2 canonical axes accounted together for $26.5 \%$ of the dispersion in the species data. Axis I: $17.4 \%$ of the variation ( $p=0.001$ after 999 permutations); axis II: $9.1 \%$ of the variation ( $p=0.016$ after 999 permutations). The overall canonical species-environment relationship was significant $(\mathrm{p}=0.019)$. (B) Species presence-absence dispersion related to substratum and flow on S\&M. The first 2 canonical axes accounted together for $25.2 \%$ of the dispersion in the species data. Axis I: $16.8 \%$ of the variation ( $p=0.001$ after 999 permutations); axis II: $8.4 \%$ of the variation $(p=0.002$ after 999 permutations). The overall canonical species-environment relationship was significant $(\mathrm{p}=0.002)$. (C) Relative species density dispersion related to substratum and flow on Fountain. The first 2 canonical axes accounted together for $28.1 \%$ of the dispersion in the species data. Axis I: $20.4 \%$ of the variation ( $p=0.001$ after 999 permutations); axis II: $7.7 \%$ of the variation ( $p=1.000$ after 999 permutations). Only axis I was significant; the overall canonical species-environment relationship was significant ( $p=0.04)$. (D) Relative species density dispersion related to substratum and flow on S\&M. The first 2 canonical axes accounted together for $27.7 \%$ of the dispersion in the species data. Axis I: $15.7 \%$ of the variation ( $\mathrm{p}=0.001$ after 999 permutations); axis II: $12 \%$ of the variation ( $p=0.005$ after 999 permutations). The overall canonical species-environment relationship was significant $(p=0.003)$. See Fig. 6 for abbreviations

Paralvinella palmiformis presence was associated with high hydrogen sulfide concentrations on both structures (Fig. 6, Table 4). Gastropods and Lepidonotopodium piscesae (LEPI) on Fountain, as well as Ridgeia piscesae and filamentous bacteria presence on S\&M, were also related to high hydrogen sulfide concentrations (Fig. 6, Table 4). The presence of $R$. piscesae and Paralvinella sulfincola on Fountain, as well as polynoids (POLY) (including $L$. piscesae) on S\&M, was either unaffected by hydrogen sulfide or associated with intermediate values. Senescent $R$. piscesae presence was associated with low hydrogen sulfide concentrations on both structures (Fig. 6A,B, Table 4). Fila- mentous bacteria, polynoids and pycnogonids on Fountain, as well as large mobile species (MOBI) and pycnogonids (PYCN) presence on S\&M, were also linked to low hydrogen sulfide concentrations (Fig. 6A,B, Table 4).

On Fountain, higher densities of Paralvinella palmiformis and gastropods were associated with high iron and hydrogen sulfide concentrations and low manganese (Fig. 6C, Table 4). Conversely, higher Paralvinella sulfincola and Ridgeia piscesae densities were related to high manganese and low iron and hydrogen sulfide concentrations (Fig. 6C, Table 4). Polynoids and senescent $R$. piscesae densities were 
either unaffected or associated with intermediate iron and hydrogen sulfide concentrations and low manganese (Fig. 6C, Table 4). On S\&M, relative organism densities were not significantly affected by the measured physical and chemical factors.

Table 4. Summary of temperature and chemistry effects on faunal distribution according to canonical correspondence analyses (CCA) results. Species (or groups) were either associated with high concentrations of the environmental variable $(\uparrow)$, low concentrations $(\downarrow)$ or either unaffected or associated with intermediate values $\Leftrightarrow)$. (-) Absence from scan points. See Table 1 for taxonomic abbreviations

\begin{tabular}{|c|c|c|c|c|c|}
\hline \multirow[t]{2}{*}{$\begin{array}{l}\text { Abbrevi } \\
\text { ation }\end{array}$} & \multicolumn{2}{|c|}{$\begin{array}{l}\text { Presence } \\
\text { or absence }\end{array}$} & \multicolumn{3}{|c|}{$\begin{array}{l}\text { Relative } \\
\text { densities }\end{array}$} \\
\hline & $\begin{array}{c}\text { Fountain } \\
\mathrm{H}_{2} \mathrm{~S}\end{array}$ & $\begin{array}{l}\mathrm{S} \& \mathrm{M} \\
\mathrm{H}_{2} \mathrm{~S}\end{array}$ & $\begin{array}{c}\text { Fountain } \\
\mathrm{H}_{2} \mathrm{~S}\end{array}$ & $\begin{array}{c}\text { Fountain } \\
\mathrm{Mn}\end{array}$ & $\begin{array}{c}\text { Fountain } \\
\mathrm{Fe}\end{array}$ \\
\hline SULF & $\approx$ & $\uparrow$ & $\downarrow$ & $\uparrow$ & $\downarrow$ \\
\hline PALM & $\uparrow$ & $\uparrow$ & $\uparrow$ & $\uparrow$ & $\uparrow$ \\
\hline RIDG & $\approx$ & $\uparrow$ & $\downarrow$ & $\uparrow$ & $\downarrow$ \\
\hline LEPI & $\uparrow$ & $\approx$ & - & - & - \\
\hline FILB & $\downarrow$ & $\uparrow$ & - & - & - \\
\hline POLY & $\downarrow$ & $=$ & $\downarrow$ & $\downarrow$ & $\downarrow$ \\
\hline GAST & $\uparrow$ & $\approx$ & $\uparrow$ & $\downarrow$ & $\uparrow$ \\
\hline BUCC & - & $\downarrow$ & - & - & - \\
\hline PYCN & $\downarrow$ & $\downarrow$ & - & - & - \\
\hline SENR & $\downarrow$ & $\downarrow$ & $=$ & $\downarrow$ & $\approx$ \\
\hline MOBI & - & $\downarrow$ & - & - & - \\
\hline
\end{tabular}

Substratum and flow effects on species distribution

CCA also showed that faunal distributions were influenced by substratum type and visible flow intensity on both sulfide edifices (Fig. 7). Overall, these complex variables explained a higher percentage of the variance in the species data than did measured physical and chemical factors (>25\% for species presence-absence data on both structures, $20.4 \%$ for relative densities on Fountain and $27.7 \%$ on S\&M).

The distribution of species or faunal groups could not be associated with beehives. Paralvinella sulfincola presence and relative densities were closely associated with flanges on both structures (Fig. 7, Table 5). Paralvinella palmiformis and Ridgeia piscesae distributions were associated with vertical walls (Fig. 7A,B) or flanges (Fig. 7D, Table 5). Gastropods and polynoids (including Lepidonotopodium piscesae) were associated either with edifice base (Fig. 7B,D) or with vertical walls (Fig. 7A,C, Table 5). Senescent $R$. piscesae distribution was closely related to edifice base (Table 5). Peripheral species and Buccinum cf viridum (BUCC) presence was also associated with edifice base (Fig. 7A,B, Table 5). Pycnogonid distribution on S\&M was related to edifice base (Fig. 7B) or to both edifice base and vertical walls (Fig. 7D, Table 5).

Table 5. Summary of substratum and flow effects on faunal distribution according to canonical correspondence analyses (CCA) results. (+++) Species (or groups) were associated with a particular substratum type; $(+)$ scores plotted between 2 types of substratum. Species (or groups) were either associated with high flow intensity ( $\uparrow$ ), low flow intensity ( $\downarrow$ ) or either unaffected or associated with intermediate values $\Leftrightarrow$. $(-)$ Absence from scan points. Since no links were found between faunal distribution and beehive substratum, the latter was not included in the present summary. See Table 1 for taxonomic abbreviations

\begin{tabular}{|c|c|c|c|c|c|c|c|c|}
\hline \multirow[t]{2}{*}{ Abbreviation } & \multicolumn{4}{|c|}{ Fountain } & \multicolumn{4}{|c|}{$\mathrm{S} \& \mathrm{M}$} \\
\hline & Flanges & $\begin{array}{c}\text { Vertical } \\
\text { walls }\end{array}$ & $\begin{array}{c}\text { Edifice } \\
\text { base }\end{array}$ & $\begin{array}{c}\text { Flow } \\
\text { intensity }\end{array}$ & Flanges & $\begin{array}{c}\text { Vertical } \\
\text { walls }\end{array}$ & $\begin{array}{c}\text { Edifice } \\
\text { base }\end{array}$ & $\begin{array}{c}\text { Flow } \\
\text { intensity }\end{array}$ \\
\hline \multicolumn{9}{|c|}{ Presence or absence } \\
\hline SULF & +++ & & & $\uparrow$ & +++ & & & $\uparrow$ \\
\hline PALM & & +++ & & $=$ & & +++ & & $\uparrow$ \\
\hline RIDG & & +++ & & $\approx$ & & +++ & & $\uparrow$ \\
\hline LEPI & & +++ & & $\downarrow$ & & +++ & & $\uparrow$ \\
\hline FILB & + & + & & $\uparrow$ & & & +++ & $\downarrow$ \\
\hline POLY & & +++ & & $\downarrow$ & & & +++ & $\downarrow$ \\
\hline GAST & & +++ & & $\downarrow$ & & & +++ & $\approx$ \\
\hline BUCC & & & & - & & & +++ & $\downarrow$ \\
\hline PYCN & & +++ & & $\downarrow$ & & & +++ & $\downarrow$ \\
\hline SENR & & & +++ & $\downarrow$ & & & +++ & $\downarrow$ \\
\hline MOBI & & & & - & & & +++ & $\downarrow$ \\
\hline \multicolumn{9}{|c|}{ Relative density } \\
\hline SULF & +++ & & & $\uparrow$ & +++ & & & $\uparrow$ \\
\hline PALM & +++ & & & $\uparrow$ & & +++ & & $=$ \\
\hline RIDG & & +++ & & $\downarrow$ & & & & $\uparrow$ \\
\hline LEPI & & & & - & & & +++ & $\approx$ \\
\hline POLY & + & + & & $\uparrow$ & & & +++ & $\downarrow$ \\
\hline GAST & + & + & & $\uparrow$ & & + & + & $\downarrow$ \\
\hline PYCN & & & & - & & + & + & 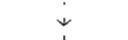 \\
\hline MOBI & & & +++ & $\downarrow$ & & & +++ & $\downarrow$ \\
\hline
\end{tabular}


A

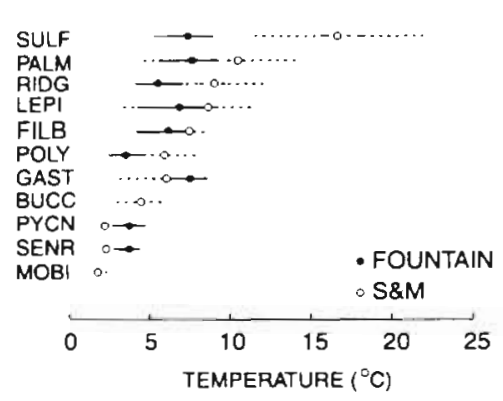

B

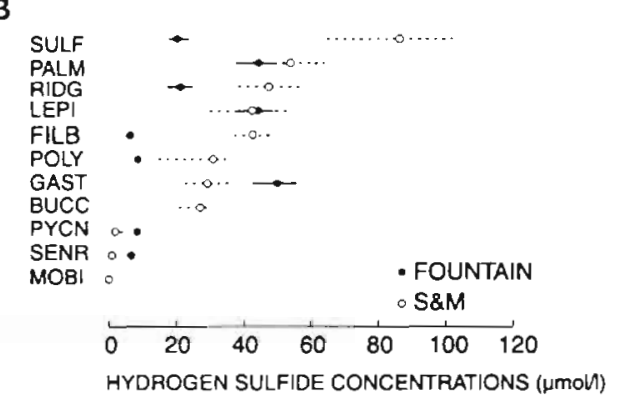

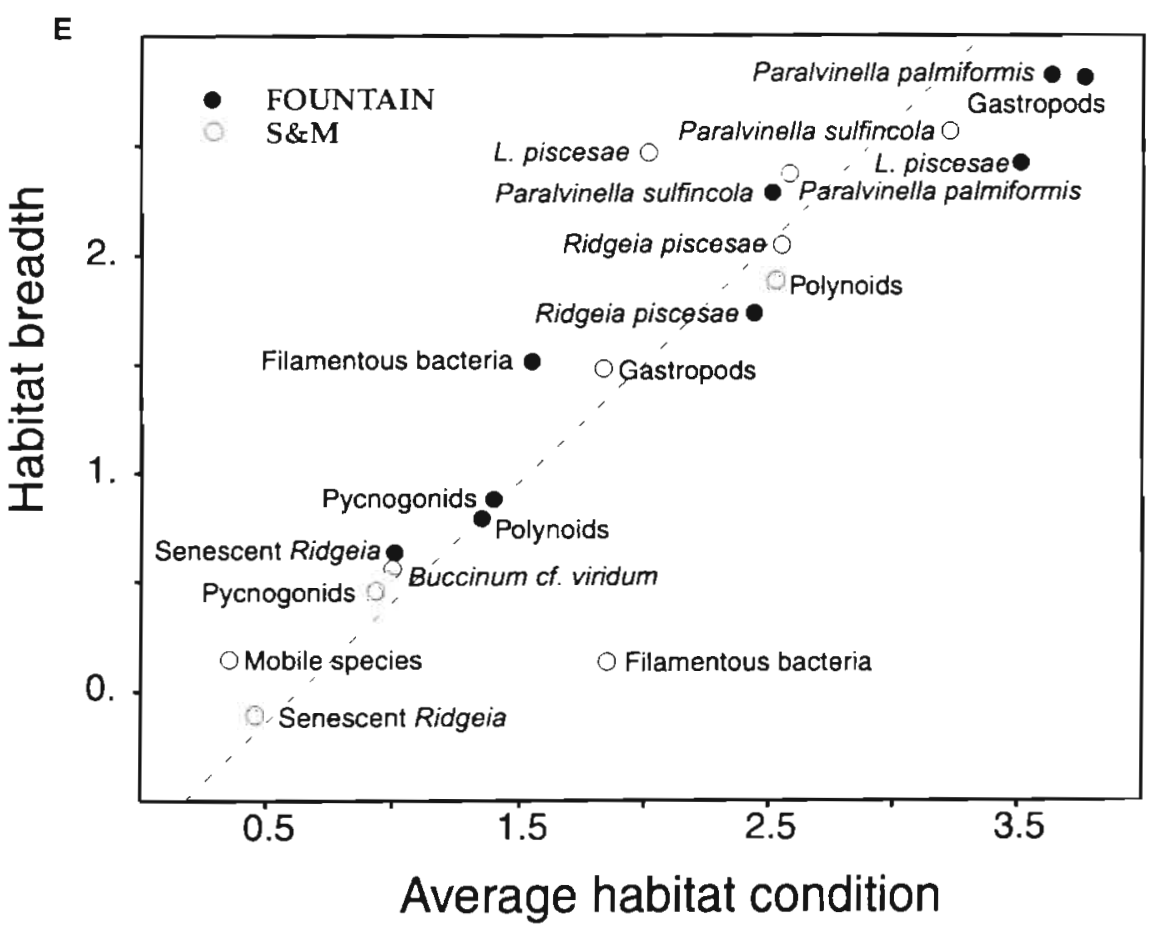

C

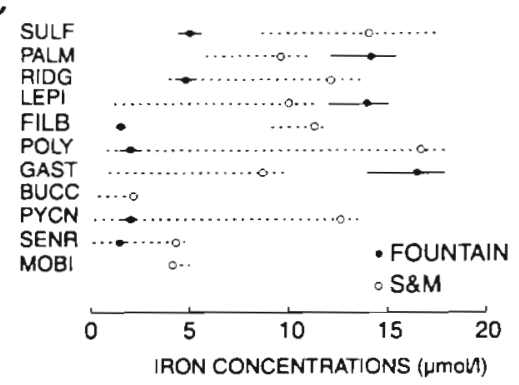

D

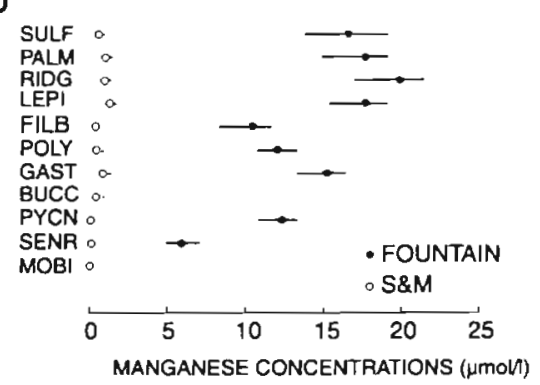

Fig. 8. Mean, minimal and maximal fluid temperatures and dissolved chemical concentrations experienced by different species or faunal groups on the 2 sulfide edifices. (A) Temperature. (B) Hydrogen sulfide. (C) Iron. (D) Manganese. Lines are ranges (solid lines: Fountain, dotted lines: $S \& M$ ). (E) Normalized indices of mean habitat condition and habitat breadth for each species and faunal groups on both sulfide edifices. The regression line was obtained from the pooled data (Fountain $+\mathrm{S} \& \mathrm{M} ; \mathrm{R}=0.98, \mathrm{p}<$ $0.01)$. Linear correlations for individual structures were significant $\left(R^{2}=0.97\right.$ for Fountain $R^{2}=0.88$ for $S \& M$ : significant $\left.p<0.01\right)$. In all panels: $(\bullet)$ Fountain species; $(0)$ S\&M species. See Fig. 6 for abbreviations

Paralvinella sulfincola, Paralvinella palmiformis and Ridgeia piscesae presences were linked with high flow intensity (Fig. 7A,B, Table 5). Buccinum of viridum, pycnogonids, senescent $R$. piscesae and large mobile species distributions were linked to low flow intensity (Fig. 7A,B,D, Table 5). For the other faunal groups, trends varied between the 2 structures: filamentous bacteria presence was linked to high flow on Fountain (Fig. $7 \mathrm{~A}$ ) while on S\&M it was linked to low flow (Fig. 7B, Table 5). The same trend applied to Lepidonotopodium piscesae presence (Fig. $7 \mathrm{~A}, \mathrm{~B})$ as well as to gastropod and polynoid relative densities (Fig. 7C,D, Table 5).
Species physical and chemical niches

Mean habitat temperature and sulfide concentrations for all species on S\&M tended to be slightly higher than on Fountain (Fig. 8A,B). Average habitat iron concentrations were usually much higher on S\&M while manganese values for habitats on Fountain were consistently 5 to 20 times higher than on S\&M (Table 1b, Fig. 8C,D). There was a strong trend for species to rank similarly with respect to mean values of temperature and chemical concentrations measured in their habitat (Fig. 8A to D). The 2 alvinellid species (Paralvinella palmiformis and Paralvinella sulfincola) 
were associated with the highest mean values whereas senescent Ridgeia piscesae and large mobile species habitats showed the weakest mean hydrothermal signal (Fig. 8A to D).

For the species (or groups) considered here, the normalized global indices of mean habitat condition and habitat breadth were highly correlated (Fig. 8E). Thus species occupying the most severe average habitat also occurred over the widest range of conditions, and vice versa. The ranking of species according to mean measured temperature and chemical values (Figs. 8A to $D$ ) is maintained in the more elaborate average habitat condition versus habitat breadth classification (Fig. 8E). Polynoids and filamentous bacteria showed the greatest differences between the 2 structures. The polynoid index points fell along the general trend whereas filamentous bacteria showed similar mean habitat scores but very different values for habitat breadth (0.64 to 2.02). For Lepidonotopodium piscesae, average habitat and habitat breadth on Fountain were among the most extreme, whereas in S\&M scans mean habitat conditions for this species were intermediate. Gastropods, Paralvinella palmiformis and $L$. piscesae were the most extremophile and tolerant species on Fountain, while on S\&M only Paralvinella sulfincola occupied the end of the spectrum. P. palmiformis and L. piscesae were found in milder habitat conditions on $\mathrm{S} \& \mathrm{M}$ than on Fountain. Vestimentiferans (Ridgeia piscesae) occurred under intermediate conditions on both structures. Buccinum of viridum, pycnogonids, senescent $R$. piscesae and large mobile species (observed only on S\&M) were limited to a narrow range of diluted hydrothermal conditions (Fig. 8E).

\section{DISCUSSION}

\section{Role of physical and chemical factors in vent ecology}

Since the beginning of hydrothermal vent biological studies, the extreme spatial and temporal variability of this milieu has been much discussed (Lonsdale 1977, Corliss et al. 1979, Enright et al. 1981, Hessler \& Smithey 1983). More recently, microcartographic and time series studies (Fustec et al. 1987, Tunnicliffe \& Juniper 1990, Chevaldonné et al. 1991, Hannington \& Juniper 1992, Chevaldonné \& Jollivet 1993, Jollivet 1993, Desbruyères 1995, Sarrazin et al. 1997) have provided quantitative support for these early observations and underlined the likely importance of environmental factors to the distribution of vent organisms.

Temperature can limit the presence of faunal species and have a selective effect on the composition of the microbial community (Karl 1985, 1995). It can also be considered as a quasi-conservative tracer (review by
Johnson et al. 1988a) of the degree of mixing between hydrothermal fluids and seawater; it is highly correlated with hydrogen sulfide (positively) and oxygen (negatively) concentrations (Johnson et al. 1986b, 1988b) and also, as observed here, with iron and manganese concentrations and visible flow intensity. $\mathrm{H}_{2} \mathrm{~S}$ is important to bacterial biomass production at vents, but can exclude faunal species by inhibiting aerobic respiration (i.e. Somero et al. 1989) and, together with dissolved metals, can lead to progressive encrustation and burial of organisms by sulfide mineral precipitates (Haymon \& Koski 1985).

Potential biological effects of micromolar concentrations of iron and manganese, normally present as trace elements (nanomolar concentrations) in seawater, are less understood (Cosson 1996). Some authors have suggested that iron could act as a rechargeable buffer against hydrogen sulfide (Oeschger \& Janssen 1991). Iron can also stimulate the growth of iron-oxidizing bacteria but can have negative effects by encrusting vent organisms (Tunnicliffe \& Fontaine 1987, Juniper \& Tebo 1995). With regard to manganese, Johnson et al. (1988a) concluded that this metal did not appear to be consumed by the vent community in the Rose Garden vent field (Galapagos spreading center). Trace metal toxicity is also a possible factor restricting species distributions. Potential toxic effects of Mn cannot be discounted since manganese is known to be toxic in marine organisms at concentrations of $<1 \mu \mathrm{mol} \mathrm{l}^{-1}$ (Ketchum 1980). Alternatively, both Fe and Mn levels could be indicative of microbial production or unmeasured fluid properties that are important to vent organisms, such as suspended particulate load or heavy metal concentrations.

\section{Differences between Fountain and S\&M}

It is important to consider whether or not our limited data series provide an accurate portrayal of the overall faunal and environmental patterns of the 2 edifices. The representative nature of the scan data is supported by the fact that measured environmental conditions on the 2 edifices were concordant with high-temperature fluid properties repeatedly observed by other authors. High-temperature fluids $\left(329\right.$ to $369^{\circ} \mathrm{C}$ ) from $\mathrm{S} \& \mathrm{M}$ are rich in $\mathrm{H}_{2} \mathrm{~S}$, whereas metals dominate in the Fountain high-temperature $\left(275\right.$ to $\left.310^{\circ} \mathrm{C}\right)$ chemistry (Butterfield \& Massoth 1994). $\mathrm{H}_{2} \mathrm{~S}$ was nearly 2 times higher in S\&M scans than on Fountain, while Fountain scans had $>20$ times more manganese than S\&M. Thus, despite dilution of high-temperature fluids prior to diffuse venting, the basic chemical signature was conserved. Nevertheless, the high-temperature Fe:Mn ratio (2.76 at Fountain, Butterfield \& Massoth 1994; 
2.47 at S\&M, von Damm 1995) was not conserved in the measured diffuse fluids which showed considerable depletion of Fe in relation to Mn. Loss of dissolved Fe can be attributed to iron sulfide precipitation during diffusion of fluids through the edifice walls (Hannington et al. 1995. Tivey 1995), to oxidation (to form $\mathrm{FeOOH}_{i}$ Millero et al. 1987) or to continued loss to form FeS outside of the chimney wall.

Mean total faunal density in S\&M scans was more than twice that of Fountain. Since $\mathrm{H}_{2} \mathrm{~S}$ is considered to be the main energy source for primary productivity at vents, differences in faunal density could result from differences in $\mathrm{H}_{2} \mathrm{~S}$ availability. However, there was no significant linear relationship between total faunal density and $\mathrm{H}_{2} \mathrm{~S}$ concentrations at either study site Total density in relation to physical and chemical factors showed a slight tendency to be maximal at intermediate values on Fountain ( $R=0.43$, not significant) while no trend was apparent on $S \& M(R=0.24$, not significant).

\section{Faunal distribution}

Several previous studies have reported high spatial heterogeneity of vent species and communities (Grassle 1985, Hessler et al. 1985, Fustec et al. 1987, Fisher 1988a,b, Chevaldonné \& Jollivet 1993, Jollivet 1993 Sarrazin et al. 1997). CA permitted us to statistically describe faunal heterogeneity (distribution of species among scan points); results agree with previous microcartographic analyses of faunal distribution. In particular, Paralvinella sulfincola and senescent Ridgeia piscesae showed distinct distributions. The latter species tended to be strongly associated with weak hydrothermal flow at the edifice base whereas $P$. sulfincola was restricted to structure walls and summits. Senescent $R$. piscesae indicate areas where local flow interruption has caused the death of these sessile animals (Sarrazin et al. 1997). Such areas should also be unsuitable for other fluid-dependent vent organisms, explaining their segregation in the CA. Similarly, $P$. sulfincola often occurs in monospecific populations (Tunnicliffe et al. 1993, Sarrazin et al. 1997), resulting in a distinct spatial distribution compared to other species.

Ridgeia piscesae, gastropods and Paralvinella palmiformis tended to group together. Alvinellidae of the genus Paralvinella are frequently associated with vestimentiferan worms (Desbruyères et al. 1985, Tunnicliffe \& Juniper 1990). These species are the major components of 3 recurring faunal assemblages (III, IV, $\mathrm{V}$ ) that form part of an overall mosaic community (Sarrazin et al. 1997, Sarrazin \& Juniper 1999). These faunal assemblages have been observed on high-temper- ature edifices all along the Juan de Fuca Ridge. Given adequate hydrothermal output, Assemblage III, dominated by gastropods and $P$. palmiformis, slowly evolves through Assemblages IV and $V$ with the progressive growth of juvenile $R$. piscesae (Sarrazin et al. 1997)

\section{Faunal relationships with environmental factors}

The CCA provide statistical support for the hypothesis that species distributions on sulfide edifices are influenced by physical and chemical factors. Hydrogen sulfide concentration, visible flow intensity and substrata emerged as the principal factors significantly influencing species distributions on both edifices.

The importance of the complex variables (visible flow and substratum) was a surprising result. These variables explained a greater percentage of the variance in species distributions than did the measured factors. Visible flow and substratum type probably reflect the influence of an ensemble of both measured and unmeasured factors (food supply, $\mathrm{O}_{2}$, etc.) on species distribution. Flow, in particular, may be an important variable influencing $\mathrm{O}_{2}$ availability, suspended particle flux and supply of dissolved $\mathrm{H}_{2} \mathrm{~S}$ for autotrophic microbial growth. Sarrazin et al. (1997) have recently demonstrated the importance of flow changes to community structure and distribution during a $3 \mathrm{yr}$ study of S\&M. The flow index is highly dependent on the observer, and on the quality of video imagery. In situ measurements will be necessary to define its precise role in species distribution.

While temperature did not emerge as a significant factor in this study, a rather narrow subset $\left(-2\right.$ to $\left.40^{\circ} \mathrm{C}\right)$ of the potential range of vent temperatures was included in the scans, and no observed temperatures exceeded levels known to be limiting to metazoans $\left(\sim 60^{\circ} \mathrm{C}\right.$; Brock 1986). Also, strong correlations observed between temperature and hydrogen sulfide concentrations could have masked the effect of temperature on faunal distribution in the $\mathrm{CCA}_{1} \mathrm{H}_{2} \mathrm{~S}$ being a more significant factor (Legendre \& Legendre 1998). The role of iron and manganese in hydrothermal species distribution is difficult to assess without more knowledge of toxic effects and possible co-variance with food availability.

\section{Niche characterization}

The indices of habitat breadth and average habitat condition are based on in situ measurement of temperature and chemical factors (temperature, $\mathrm{H}_{2} \mathrm{~S}, \mathrm{Mn}^{2+}$ and $\mathrm{Fe}^{2+}$ ) and visual determination of species distributions among scan points. They provide an objective 
and quantitative characterization of species niches and a basis for developing ecological hypotheses. We considered weighting the variables to account for the lessunderstood, direct influences of iron and manganese on species. However, since toxic effects of these 2 variables are a possibility, all factors were given equal weighting. Despite differences in overall fluid chemistry of the 2 sulfide edifices, species niches were largely concordant. Some species were able to exist over a wide range of conditions, whereas others appeared to have strict habitat requirements. Based on video observations at $13^{\circ} \mathrm{N}$ on the East Pacific Rise, Fustec et al. (1987) classified vent species according to their affinity for high-temperature, element-rich emissions: alvinellid polychaetes restricted to high-temperature areas were called 'strict eulithophiles', low-temperature species such as vestimentiferans were 'strict oligolithophiles', whereas species associated to a larger range of conditions were considered to be 'tolerant oligolithophiles'. This classification does not take into account extreme values experienced by different species in their habitats, which can be physiologically limiting (Chevaldonné et al. 1991)

According to Tunnicliffe et al. (1993), Paralvinella sulfincola overlaps with Paralvinella palmiformis in its ecological niche in areas of lower water flow, while Martineu et al. (1997) suggest that $P$. sulfincola is adapted to more severe hydrothermal conditions than $P$. palmiformis. Little niche separation between these 2 species was evident here, probably because temperatures recorded around $P$. sulfincola were below the maximum encountered by this species $\left(20\right.$ to $80^{\circ} \mathrm{C}$, Juniper et al. 1992), due to operational limitations. $P$. palmiformis and $P$. sulfincola occupy a niche similar to the other group of Alvinellidae, the alvinellids Alvinella pompejana and A. caudata. Their preferred habitat was at the upper end of the spectrum but they were also regularly present under less severe conditions among Ridgeia piscesae. Because of their dissimilar niche indices on the 2 sulfide edifices, the polynoids and filamentous bacteria might be considered as tolerant organisms rather than as organisms that systematically occupy a broad niche. Gastropods also appeared to be of the tolerant type, which is in agreement with the niche description (based on temperature) of Laubier \& Desbruyères (1985, in Gaill \& Hunt 1991), where gastropods in different sites at $13^{\circ} \mathrm{N}$ occurred at temperatures ranging from ambient to almost $30^{\circ} \mathrm{C}$.

This categorization of species according to niche breadth and average habitat condition could eventually be used to model species distributions in relation to environmental change (Sarrazin et al. 1997). However, as mentioned above, the upper niche limits of the more broadly ranging species (e.g. Paralvinella palmiformis; Fig $8 \mathrm{E}$ ) still remain to be determined.

\section{Physiological tolerance/requirements}

The physiological requirements and tolerance capacities of most vent organisms remain poorly defined. Known adaptive mechanisms, particularly those related to sulfide acquisition and detoxification, provide some insights into how several Juan de Fuca species manage to occupy either broadly ranging or severe habitats.

High affinity sulfide-binding proteins in blood allow sulfide-dependent vestimentifera to survive and even grow at low-sulfide concentrations (Childress et al. 1984, 1991), and other species to tolerate the presence of $\mathrm{H}_{2} \mathrm{~S}$. Sulfide binding by blood proteins in Ridgeia piscesae has been little investigated. Paralvinella palmiformis has sulfide-binding proteins in its blood (Martineu et al. 1997) and both P. palmiformis and Paralvinella sulfincola have elevated sulfide detoxification capacity in their tissues (Martineu \& Juniper 1997). These adaptations may be critical to exploitation of food resources in the presence of significant concentrations of $\mathrm{H}_{2} \mathrm{~S}$. Tissue-level sulfide detoxification appears to be relatively common among benthic polychaetes and may explain the success of these worms in colonizing the vent environment worldwide (Martineu \& Juniper 1997).

Some species distributions can also be explained in terms of the absence of mechanisms for coping with hydrothermal fluids. The high biomass produced around vents provides an assured food source for predators and scavengers, but many peripheral species appear to be restricted to low-temperature areas because dissolved $\mathrm{H}_{2} \mathrm{~S}$ and suspended particles may interfere with respiration (Tunnicliffe \& Jensen 1987). The large yellow snail Buccinum cf viridum, and large mobile species (vent fish, spider crab and shrimp) were associated with low concentrations of chemical species and low-flow intensity on both structures. Their preferred habitat appeared to be the base of the edifice. Pycnogonids were also associated with a weak hydrothermal signal at the edifice base.

\section{Interaction between species}

Interactions between species that might affect distribution patterns have been observed in the hydrothermal vent environment. Particularly relevant to the present study are species co-occurrences related to habitat modification or nutritional resources. For example, the extensive 3-dimensional structure created by tubes of the vestimentiferan Ridgeia piscesae can greatly increase (up to 28 times) space available for colonization by other sulfide edifice species, there- 
by augmenting organism density per $\mathrm{m}^{2}$ of edifice surface (Sarrazin \& Juniper 1999). Thus, interpretation of relative species density in the presence of $R$. piscesae must also take this habitat expansion effect into account, as well as consider the direct influence of temperature and chemistry on individual species. The close association of the small gastropods and Paralvinella palmiformis with $R$. piscesae in the CA may be related to this effect.

Vestimentiferan tubes also provide a surface for colonization by free-living bacteria, a likely source of nutrition for deposit feeders. However, there are presently no quantitative data available regarding bacterial biomass on Ridgeia piscesae tubes or the importance of this food source to individual faunal species. In contrast, Paralvinella palmiformis is known to be an important source of detritus in Juan de Fuca vent communities, through the secretion and sloughing off of epidermal mucus (Juniper et al. 1986 . Juniper 1988). The mucus is subsequently colonized by microorganisms (Juniper 1988) and can accumulate in large macroscopic aggregations (Tunnicliffe et al. 1986). The close statistical association of pycnogonids with $P$. palmiformis in the lower range of the worm's habitat may indicate a nutritional dependence on mucus debris (Juniper et al. 1986). Although little is known about their diet, Child (1987) proposed that they could feed on available vestimentiferans, palm worms, vent-associated bacteria or mucus.

\section{Nutritional mode}

Nutritional mode is likely to influence choice of habitat, yet with the exception of symbioses and obvious predation, this aspect of hydrothermal vent ecology remains poorly known. Table 6 summarizes present understanding of the autotrophic and heterotrophic nutritional modes for the organisms examined here.

Invertebrates that have an obligatory relationship with endosymbiotic chemoautotrophic bacteria (Cavanaugh et al. 1981, Felbeck 1981, Childress \& Fisher 1992), such as Ridgeia piscesae, are restricted to interface areas where both oxidants (primarily oxygen) and reductants (in this case hydrogen sulfide) are present (Fisher 1990, Johnson et al. 1994, Nelson \& Fisher 1995). A time-series cartographic study by Sarrazin et al. (1997) showed $R$. piscesae-dominated assemblages to be the most abundant and stable faunal assemblages on hydrothermal edifices of the Juan de Fuca Ridge. In the CCA, $R$, piscesae showed 2 patterns in relation to hydrogen sulfide and flow. On Fountain its distribution was rather unaffected or related to intermediate sulfide concentrations and flow intensity, while on S\&M it was associated with high sulfide and flow. On both edifices, $R$. piscesae was associated with edifice wall substrata

Several studies have shown alvinellid polychaetes to have a preference for extreme habitat conditions (reviewed by Chevaldonné 1996), and some propose

Table 6. Summary of present knowledge of nutritional mode of hydrothermal vent organisms or faunal groups examined in the present study

\begin{tabular}{|lll|}
\hline Organism & \multicolumn{1}{c}{ Nutritional mode } & \\
\hline Ridgeia piscesae & Obligate symbiosis with sulfide oxidizing microorganisms & Cavanaugh et al. (1981) \\
& & $\begin{array}{c}\text { Felbeck (1981) } \\
\text { Childress \& Fisher (1992) }\end{array}$ \\
Paralvinella sulfincola & Deposit feeding on newly formed sulfide surfaces & Tunnicliffe et al. (1993) \\
& & Juniper (1994) \\
Paralvinella palmiformis & Suspension and/or deposit feeding & Juniper \& Martineu (1995) \\
Lepidonotopodium piscesae & Likely grazing or predation. & Desbruyères \& Laubier (1991) \\
& Unknown relationship with epizooic bacterial growth on scales & Pettibone (1988) \\
Other polynoid polychaetes & Unknown. Likely grazing or predation & Tunnicliffe et al. (1990) \\
& Guts full of bacterial filaments & Tunnicliffe (pers. comm.) \\
Filamentous bacteria & Mainly sulfide oxidation & Jannasch \& Nelson (1984) \\
Buccinum cf. viridum & Grazing & Jannasch \& Wirsen (1985) \\
Other gastropods & Grazing and/or filter feeding & Martell (1997) \\
Large mobile species & Predation and scavenging & deBurgh \& Singla (1984) \\
Pycnogonids & Grazing or deposit feeding & Tunnicliffe \& Jensen (1987) \\
& Grazing & Child (1987) \\
& & Brescia \& Tunnicliffe (1998)
\end{tabular}


exclusive access to a food source as an explanation for this behavior (Juniper \& Martineu 1995). Juniper (1994) suggests that Paralvinella sulfincola may feed on hyperthermophilic bacteria growing on sulfide surfaces. Paralvinella palmiformis was most abundant where visible flow was most intense. Although this suspension-feeding polychaete species has no direct sulfide requirements (Desbruyères \& Laubier 1991), high-flow areas could be favorable to suspension feeding.

If microbial gardening or ectosymbiosis were important elements of an animal's nutritional strategy, habitat selection could conceivably be influenced by requirements for microbial growth. Several forms of bacterial epibiosis have been described for the species considered here, but their nutritional role is unknown. Bacteria colonize the inner and outer surfaces of the tubes of Paralvinella sulfincola (Juniper 1994), create the hirsute form of Lepidonotopodium piscesae by attaching to the worm's dorsal scales (Pettibone 1988) and insert into the branchial tissues of the limpet Lepetodrilus fucensis (de Burgh \& Singla 1984). Also, our data can be interpreted to show that epizooic bacteria colonizing the hirsute form of $L$. piscesae were generally exposed to a stronger hydrothermal signal than free-living filamentous bacteria on rock or vestimentiferan tube surfaces. However, there is presently no information on the physiological requirements of the polynoid epizooic bacteria as compared to other filamentous forms observed sulfide edifices, or on the importance of either as a food source for vent animals.

\section{CONCLUSION-UNEXPLAINED VARIANCE}

While humanity has spent around 1 million yr trying to understand nature and formulating hypotheses on the causes of natural variability, only a few years have been devoted to understanding and explaining observed variability at hydrothermal vents. With this study, we explain about $30 \%$ of the variability in species distribution. These results may now be used as bases for elaboration of more encompassing theories. A first step is a critical consideration of how to account for the $70 \%$ of the variance in species data that could not be attributed to measured factors.

\section{Methodological limitations}

Organism abundances evaluated from video imagery are likely to be underestimated because neither the thickness of the faunal cover nor the presence of meiofauna can be estimated. For some scans it was also difficult to accurately determine abun- dance. Similarly, the density used in this study is only semi-quantitative and could result in differing degrees of underestimation.

Tube dwelling and behavioral adaptations (Paralvinella sulfincola, Ridgeia piscesae) will also influence the environmental conditions that are experienced by some hydrothermal species. Thus, single point measurements taken with the SUAVE will only give an approximate niche for these species. Scan locations were often determined by submersible accessibility rather than by a pre-established random sampling protocol, particularly on the steep vertical walls of the edifices. Some habitats, particularly the more severe ones on the upper parts of the structures, were difficult to reach with the sampling probe and may be under-represented. Certain species niches, especially for $P$. sulfincola, likely extended beyond the environmental conditions measured by the chemical analyzer (Juniper et al. 1992). Longer sequences (that are $24 \mathrm{~h}$ or more and cover the full range of tidal periodicity) could provide more complete information on average habitat conditions and niche breadth. However, multiple long-term deployments of the present generation of SUAVE or similar devices are logistically difficult and unlikely to be available to ecologists in the near future. Similarly, the acquisition of 78 SUAVE scans required in excess of $40 \mathrm{~h}$ of submersible bottom time, so it is unlikely that future comparative studies with this type of instrument will be able to collect substantially more chemical and temperature information. Finally, temperature and fluid chemistry at the probe tip may have been affected by water currents created by the operation of the ROV thrusters, inducing potential errors in determining habitat conditions.

\section{Unmeasured environmental factors}

Deep-sea in situ analyzers are very few and were originally built for chemistry interests. Oxygen is known to be an important factor for vent species, especially for chemoautotrophic organisms and for metazoan survival (Childress et al. 1984, Johnson et al. 1988a, Juniper \& Martineu 1995). Johnson et al. (1988b) have shown that some species, like the vestimentiferan Riftia pachyptila, were more adapted to habitats that fluctuate rapidly between oxic and anoxic conditions, while others, such as the clam Calyptogena magnifica, seemed better suited to environments displaying less variability. Turbulent mixing and resulting temporal fluctuations of environmental conditions are probably essential to the survival of alvinellid species (genus Paralvinella), since small amounts of dissolved oxygen can be periodically 
available (Juniper \& Martineu 1995). Nitrogen compounds are consumed by symbiotic and free-living microorganisms (Felbeck et al. 1985), probably not only to meet their metabolic nitrogen requirements but also as a terminal electron acceptor in the absence of oxygen (Hentschel \& Felbeck 1993). In flowing water environments, simple measures of chemical concentration may themselves be inadequate descriptors of vent habitat, since supply of dissolved substances is controlled by both concentration and flow rate. The latter point is supported by the demonstrated importance of fluid flow in determining organism distribution in this study.

In addition to existing local physical and chemical factors, the spatio-temporal distribution of the different species is the result of the colonization history and succession of populations, factors that were not taken into account here. Finally, very little is known about food availability for deposit- and suspension-feeding species at vents. It is likely that faunal distribution and density on sulfide edifices will be influenced by the availability of different food resources. Quantification of bacterial biomass and organic debris on surfaces and suspended in fluids may provide important insight into species distribution, feeding mode and niche separation (Juniper 1994).

\section{Biological succession}

In addition to environmental factors, biological succession probably plays a role in vent species distributions, even though the extreme nature of the sulfide edifice habitat and the short time scale on which change operates may often prevent communities from developing significant biological interactions before being restructured by physical disruption (Tunnicliffe \& Juniper 1990, van Dover 1995, Sarrazin et al. 1997). Hessler et al. (1988) attribute community changes over time at the Galapagos low-temperature vents to biological interactions such as competition and/or predation rather than to environmental conditions. Sarrazin et al. (1997) proposed that hydrothermal community transitions on sulfide edifices are driven by flow variations and biological processes operating at sub-annual time scales. The species and groups examined in this study appear to colonize a definable physical and chemical niche, in which case their continued presence in a given area should be initially dependent upon the maintenance of required environmental conditions.

In their dynamic succession model, Sarrazin et al. (1997) suggested that community transitions are the result of gradual environmental change, perturbations

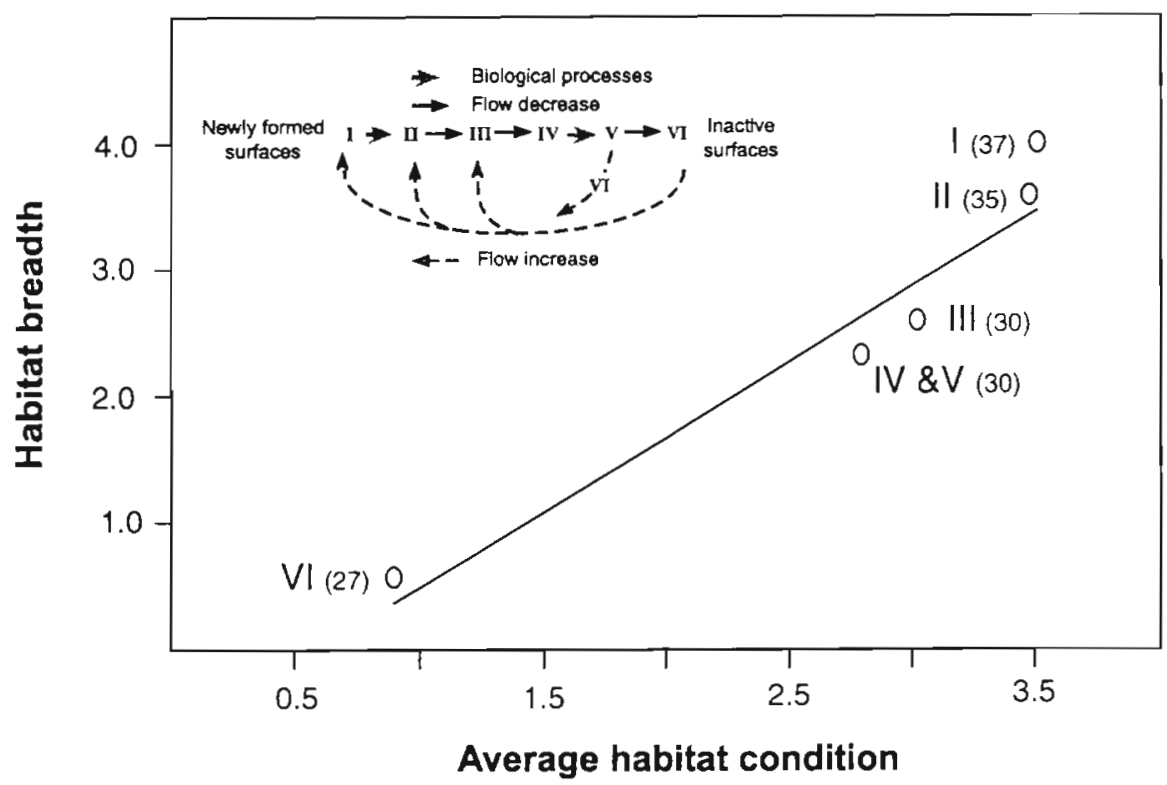

Fig. 9. Normalized (as per Fig. 8E) indices of mean habitat condition and habitat breadth for 6 faunal assemblages that colonize high-temperature sulfide edifices of the Juan de Fuca Ridge (see Sarrazin et al. 1997, Sarrazin \& Juniper 1999 for details). The niche for each faunal assemblage was determined by plotting average habitat condition against habitat breadth obtained for the 1 or 2 species that dominated the biomass of that assemblage (Sarrazin \& Juniper 1999), using pooled SUAVE scan data from both edifices examined in this study. For example, Paralvinella sulfincola constitutes more than $50 \%$ of Assemblage I biomass. The calculated niche of this species was used as an indicator of the Assemblage I niche. Pooled SUAVE data for the edifice base, vertical walls, flanges and beehives served to define the normalized mean and range of habitat conditions prevailing on these substrata. Linear regression for faunal assemblage distribution was significant $\left(R^{2}=0.95, p<0.01\right)$. The model of community succession, developed by Sarrazin et al. (1997), is presented at the upper left 
and biological processes, all acting in a spatially heterogeneous and unpredictable way. The heterogeneity of such factors on a single structure results in a mosaic of distinct faunal assemblages (Sarrazin et al. 1997, Sarrazin \& Juniper 1999). The model (see Fig. 9) describes a progressive transition from colonization of new sulfide mineral surfaces by alvinellid polychaetes through development and senescence of vestimentiferan tube worm assemblages, as hydrothermal fluid supply diminishes and eventually ceases. It also provides for cases of reactivation of fluid flow on cooling surfaces, which could result in a reversion to an earlier successional stage (Sarrazin et al. 1997). The model identifies 2 transitions (I to II and IV to V) which result from biological processes that change habitat conditions primarily by modifying or adding substrata. Tube building and biomineralization by Paralvinella sulfincola allow colonization by Paralvinella palmiformis (I to II), and growth of Ridgeia piscesae tubes creates a complex 3-dimensional environment for smaller species (IV to V) (Sarrazin \& Juniper 1999). There is some analogy here to faunal dynamics in other highly disturbed marine habitats (upper intertidal, upper and shallow tide pools, boulders, and strongly exposed reef zones; Sousa 1984, Johnson et al. 1994), where community structure is primarily controlled by environmental constraints, within which biological interactions act as secondary factors in determining the spatio-temporal distributions of species. This situation does not exclude biological succession but may limit it to processes that operate over short periods of time.

Environmental factors such as $\mathrm{H}_{2} \mathrm{~S}$ concentrations, fluid flow velocity and substratum characteristics that influence the distribution of individual species will play a role in shaping faunal assemblages. As a preliminary test of this effect we estimated the average temperature and chemical niche and niche breadth for the 6 faunal assemblages described for the Juan de Fuca edifices (Sarrazin et al. 1997, Sarrazin \& Juniper 1999). Niche properties for each assemblage were derived from SUAVE data for dominant species. The 6 assemblages discriminate along an environmental gradient (Fig. 9) in accordance with the Sarrazin et al (1997) succession model. Assemblages I-II and IV-V group as pairs, showing little difference in fluid property niches, as might be expected where the I to II and IV to $\mathrm{V}$ transitions are biologically driven. Assemblages I and II occupy the most severe niche, on newly formed beehive and flange surfaces, as observed here. Subsequent Assemblages III to $\mathrm{V}$ occupy more clement habitats on edifice walls, while senescent Assemblage VI is associated with the older edifice base or other surfaces where mineralization has severely reduced hydrothermal flow from internal conduits. This projection from species niches to faunal assemblage distribu- tions supports the Sarrazin et al. (1997) hypothesis that the faunal mosaic on hydrothermal edifices is a product of environmental heterogeneity. A more critical test awaits application of an expanded suite of environmental measurements that directly target the 6 Juan de Fuca assemblages, as well as sulfide edifice faunas in other regions.

Acknowledgements. This work would not have been possible without field support by the pilots of ROPOS and the crews of the CSS 'John P. Tully' and the NOAA ship 'Discoverer'. This research was sponsored by NSERC-Canada, Fisheries and Oceans Canada and the National Science Foundation. J.S. was supported by post-graduate fellowships from NSERC (Canada), FCAR (Québec) and GÉOTOP (UQAM). We are particularly grateful to Dr Verena Tunnicliffe, Dr Lauren Mullineaux and 4 anonymous reviewers for their constructive comments on the manuscript.

\section{LITERATURE CITED}

Brescia LA, Tunnicliffe V (1998) Population biology of two pycnogonid species (Ammotheidae) at hydrotherma vents in the northeast Pacific. Cah Biol Mar 39:233-236

Brock TD (1986) Introduction: an overview of the thermophiles. In: Brock TD (ed) Thermophiles: general, molecular, and applied microbiology. Wiley, New York, p 1-16

Butterfield DA, Massoth GJ (1994) Geochemistry of North Cleft segment vent fluids: temporal changes in chlorinity and their possible relation to recent volcanism. J Geophys Res 99(B3):4951-4968

Butterfield D, Massoth GJ, McDuff RE, Lupton JE, Lilley MD (1990) Geochemistry of hydrothermal fluids from Axial Seamount Hydrothermal Emissions Study vent field, Juan de Fuca Ridge: subseafloor boiling and subsequent fluidrock interaction. J Geophys Res 95:12895-12921

Butterfield D, McDuff RE, Mottl MJ, Lilley MD, Lupton JE, Massoth GJ (1994) Gradients in the composition of hydrothermal fluids from the Endeavour segment vent field: phase separation and brine loss. J Geophys Res 99 (B5):9561-9583

Cavanaugh CM, Gardiner SL, Jones ML, Jannasch HW Waterbury JB (1981) Prokariotic cells in the hydrothermal vent tube worm Riftia pachyptila Jones: possible chemoautotrophic symbionts. Science 213:340-342

Chevaldonné $P$ (1996) Écologie des cheminées hydrothermales actives. Thèse de doctorat, Centre d'acéanologie de Marseille

Chevaldonné $P$, Jollivet $D$ (1993) Videoscopic study of deepsea hydrothermal vent alvinellid polychaete populations: biomass estimation and behaviour. Mar Ecol Prog Ser 95 $51-262$

Chevaldonné $P$, Desbruyères D, Le Haitre $M$ (1991) Timeseries of temperature from three deep-sea hydrothermal vent sites. Deep-Sea Res 38(11):1417-1430

Child CA (1987) Ammothea verenae and Sericosura venticola: two new hydrothermal vent-associated pycnogonids from the northeast Pacific. Proc Biol Soc Wash 100(4): 892-901

Childress JJ, Fisher CR (1992) The biology of hydrothermal vent animals: physiology, biochemistry, and autotrophic symbioses. Oceanogr Mar Biol Annu Rev 30:337-441

Childress JJ, Arp AE, Fisher CR (1984) Metabolic and blood 
characteristics of the hydrothermal vent tube worm Riftia pachyptila. Mar Biol 83:109-124

Childress JJ, Fisher CR, Brooks JM, Kennicutt MC II, Bidigare $\mathrm{R}$, Anderson A (1986) A methanotrophic marine molluscan symbiosis: mussels fueled by gas. Science 233:1306-1308

Childress JJ, Fisher CR, Favuzzi JA, Kochevar RE, Sanders NK, Alayse AM (1991) Sulfide-driven autotrophic balance in the bacterial symbiont-containing hydrothermal vent tube worm, Riftia pachyptila Jones. Biol Bull 180:135-153

Chin CS, Johnson KS, Coale KH (1992) Spectrophotometric determination of dissolved manganese in natural waters with 1-(2-pyridylazo)-2-naphtol: application to analysis in situ in hydrothermal plumes. Mar Chem 37:65-82

Chin CS, Coale KH, Elrod VA, Johnson KS, Massoth GJ, Baker ET (1994) In situ observations of dissolved iron and manganese in hydrothermal vent plumes, Juan de Fuca Ridge. J Geophys Res 99(B3):4969-4984

Corliss JB, Dymond J, Gordon LI, Edmond JM, Von Herzen RP, Ballard RD, Green K, Williams D, Bainbridge A, Crane $K$, van Andel TH (1979) Submarine thermal springs on the Galapagos Rift. Science 213:1073-1083

Cosson RP (1996) La bioaccumulation des éléments minéraux chez le vestimentifère Riftia pachyptila (Jones): bilan des connaissances. Oceanol Acta 19(2):163-176

Dai CF, Stewart LL, Cooper RA, Sprunk HJ (1992) Distribution of substrates and macrobenthos at depths between 35 and $120 \mathrm{~m}$ in southern Taiwan. Acta Oceanogr Taiwanica 28: $1-18$

deBurgh ME, Singla CL (1984) Bacterial colonization and endocytosis on the gill of a new limpet species from a hydrothermal vent. Mar Biol 84:1-6

Delaney JR, Robigou V, McDuff RE, Tivey MK (1992) Detailed geologic relationships of a vigorous hydrothermal system: the Endeavour vent field, northern Juan de Fuca Ridge. J Geophys Res 97:19663-19682

Desbruyères D (1995) Biological studies at the ridge crest: temporal variations of deep-sea hydrothermal communities at $13^{\circ} \mathrm{N} / E P R$. Interidge News $4: 6-10$

Desbruyères D, Laubier L (1991) Systematics, phylogeny, ecology and distribution of the Alvinellidae (Polychaeta) from deep-sea hydrothermal vents. Ophelia Suppl 5: $31-45$

Desbruyères D, Crassous P, Grassle J, Khripounoff A, Reyss D, Rio M, Van Praet $M$ (1982) Données écologiques sur un nouveau site d'hydrothermalisme actif de la ride du Pacifique oriental. CR Acad Sci Paris Sér III 295:489-494

Desbruyères D, Gaill F, Laubier L, Fouquet Y (1985) Polychaetous annelids from hydrothermal vent ecosystem: an ecological overview. In: Jones ML (ed) Hydrothermal vents of the eastern Pacific: an overview. Biol Soc Wash Bull 6:103-116

Desbruyères D, Chevaldonné $\mathrm{P}$, Alayse AM, Jollivet D, Lallier FH, Jouin-Toulmond C, Zal F, Sarradin PM, Cosson R, Caprais JC, Arndt C, O'Brien J, Guezennec J, Hourdez S, Riso R, Gaill F, Laubier L, Toulmond A (1998) Biology and ecology of the 'Pompeii worm' (AJvinella pompejana Desbruyères and Laubier), a normal dweller of an extreme deep-sea environment: a synthesis of current knowledge and recent developments. Deep-Sea Res 45:383-422

Enright JT, Newman WA, Hessler RR, McGowan JA (1981) Deep-ocean hydrothermal vent communities. Nature 289: 219-221

Felbeck H (1981) Chemoautotrophic potential of the hydrothermal vent tube worm, Riftia pachyptila Jones (Vestimentifera). Science 213:336-338

Felbeck H, Powell MA, Hand SC, Somero GN (1985) Metabolic adaptations of hydrothermal vent animals. In: Jones
ML (ed) Hydrothermal vents of the eastern Pacific: an overview. Bull Biol Soc Wash 6:261-272

Fisher CR (1990) Chemoautotrophic and methanotrophic symbioses in marine invertebrates. Rev Aquat Sci 2: $399-436$

Fisher CR, Childress JJ, Arp AJ, Brooks JM, Distel D, Favuzzi JA, Felbeck H, Hessler RR, Johnson KS, Kennicutt MC II, Macko SA, Newton A, Powell MA, Somero GN, Soto T (1988a) Microhabitat variation in the hydrothermal vent mussel, Bathymodiolus thermophlus, at the Rose Garden vent on the Galapagos Rift. Deep-Sea Res 35(10/11): $1769-1791$

Fisher CR, Childress JJ, Arp AJ, Brooks JM, Distel D, Dugan JA, Felbeck H, Fritz LW, Hessler RR, Johnson KS, Kennicutt MC II, Lutz RA, Macko SA, Newton A, Powell MA, Somero GN, Soto $\mathrm{T}$ (1988b) Variation in the hydrothermal vent clam, Calyptogena magnifica, at the at the Rose Garden vent on the Galapagos spreading center. Deep-Sea Res 35(10/11):1811-1831

Fustec AD, Desbruyères D, Juniper SK (1987) Deep-sea hydrothermal vent communities at $13^{\circ} \mathrm{N}$ on the East Pacific Rise: microdistribution and temporal variations. Biol Oceanogr 4(2):121-164

Gaill F, Hunt S (1991) The biology of annelid worms from high temperature hydrothermal vent regions. Rev Aquat Sci $4(2-3): 107-1.37$

Grassle JF (1985) Hydrothermal vent animals: distribution and biology, Science 229(4715):713-717

Grehan AJ, Juniper SK (1996) Clam distribution and subsurface hydrothermal processes at Chowder Hill (Middle Valley), Juan de Fuca Ridge. Mar Ecol Prog Ser 130:105-115

Hannington MD, Juniper SK (1992) The ecology and geological evolution of large sulfide structures: scaling up from chimney models. RIDGE Events 3(1):38-42. Ridge Office. University of New Hampshire, Durham, NH

Hannington MD, Jonasson IR, Herzig PM, Petersen S (1995) Physical and chemical processes of seafloor mineralization at mid-ocean ridges. In: Humphris SE, Zierenberg RA, Mullineaux LS, Thomson RE (eds) Seafloor hydrothermal systems: physical, chemical, biological, and geological interactions. Geophys Monogr Ser 91, American Geophysical Union, Washington, DC, p 115-157

Haymon RM, Kastner M (1981) Hot spring deposits on the East Pacific Rise at $21^{\circ} \mathrm{N}$; preliminary description of mineralogy and genesis. Earth Planet Sci Lett 53:363-381

Haymon RM, Koski RA (1985) Evidence of an ancient hydrothermal vent community: fossil worm tubes in cretaceous sulfice deposits of the Samail Ophiolite, Oman. In: Jones ML (ed) Hydrothermal vents of the eastern Pacific: an overview. Bull Biol Soc Wash 6:57-65

Hentschel U, Felbeck $H$ (1993) Nitrate respiration in the hydrothermal vent tubeworm Riftia pachyptila. Nature 366:338-340

Hessler RR, Smithey WM Jr (1983) The distribution and community structure of megafauna at the Galapagos Rift hydrothermal vents. In: Rona PA, Bostrom $\mathrm{K}$, Laubier L, Smith KL Jr (eds) Hydrothermal processes at seafloor spreading centers. Plenum Press, New York, p 735-770

Hessler RR, Smithey WM, Keller CH (1985) Spatial and temporal variation of giant clams, tubeworms and mussels at deep-sea hydrothermal vents. Bull Biol Soc Wash 6: $465-474$

Hessler RR, Smithey WM, Boudrias MA, Keller CM, Lutz RA, Childress JJ (1988) Temporal change in megafauna at the Rose Garden hydrothermal vent (Galapagos eastern tropical Pacific). Deep-Sea Res 35(10/11):1681-1709

Jannasch HW (1995) Microbial interactions with hydrother- 
mal fluids. In: Humphris SE, Zierenberg RA, Mullineaux LS, Thomson RE (eds) Seafloor hydrothermal systems: physical, chemical, biological, and geological interactions. Geophys Monogr Ser 91, Washington, DC, p 273-296

Jannasch HW, Nelson DC (1984) Recent progress in the microbiology of hydrothermal vents. In: Klug MJ, Reddy CA (eds) Current perspectives in microbial ecology. American Society of Microbiology Publication, Washington, DC, p 170-176

Jannasch HW, Mottl MJ (1985) Geomicrobiology of deep-sea hydrothermal vents. Science 229:717-725

Jannasch HW, Wirsen CO (1979) Chemosynthetic primary production at East Pacific sea floor spreading centers. Bioscience 29:592-598

Jannasch HW, Wirsen CO (1985) The biochemical versatility of chemosynthetic bacteria at deep-sea hydrothermal vents. In: Jones ML (ed) Hydrothermal vents of the eastern Pacific: an overview. Bull Biol Soc Wash 6:325-334

Johnson HP, Tunnicliffe $V$ (1985) Time-series measurements of hydrothermal activity on northern Juan de Fuca Ridge. Geophys Res Lett 12(10):685-688

Johnson KS, Beehler CL, Sakamoto-Arnold CM (1986a) A submersible flow analysis system. Anal Chim Acta 179: $245-257$

Johnson KS, Beehler CL, Sakamoto-Arnold CM, Childress JJ (1986b) In situ measurements of chemical distributions in a deep-sea hydrothermal vent field. Science 231:1139-1141

Johnson KS, Childress JJ, Beehler CL (1988a) Short-term temperature variability in the Rose Garden hydrothermal vent field: an unstable deep-sea environment. Deep-Sea Res 35(10/11):1711-1721

Johnson KS, Childress JJ, Hessler RR, Sakamoto-Anold CM, Beehler CL (1988b) Chemical and biological interactions in the Rose Garden hydrothermal vent field, Galapagos spreading center. Deep-Sea Res 35(10/11):1723-1744

Johnson KS, Childress JJ, Beehler CL, Sakamoto-Arnold CM (1994) Biogeochemistry of hydrothermal vent mussel communities: the deep-sea analogue to the intertidal zone. Deep-Sea Res 41(7):993-1011

Jollivet D (1993) Distribution et évolution de la faune associée aux sources hydrothermales profondes à $13^{\circ} \mathrm{N}$ sur la dorsale du Pacifique Oriental: le cas particulier des polychètes alvinellidae. Thèse de doctorat, Université de Bretagne Occidentale

Jones ML (1985) On the vestimentifera, new phylum: six new species, and other taxa, from hydrothermal vents and elsewhere. In: Jones ML (ed) Hydrothermal vents of the eastern Pacific: an overview. Bull Biol Soc Wash 6:117-158

Juniper SK (1988) Géochimie et écologie d'un microenvironnement hydrothermal: les sécrétions de mucus de Paralvinella palmiformis. Oceanol Acta 8:167-172

Juniper SK (1994) Ecology and biogeochemistry of Paralvinella sulfincola at northeast Pacific hydrothermal vents: review and comparison with Alvinella spp. of the east Pacific rise. In: Dauvin JC, Laubier L, Reish DJ (eds) Actes de la 4èrne Conférence Internationale des Polychètes. Mém Mus Nat Hist Natl 162:453-462

Juniper SK, Martineu $P$ (1995) Alvinellids and sulfides at hydrothermal vents of the eastern Pacific: a review. Am Zool 35:174-185

Juniper SK, Sarrazin J (1995) Interaction of vent biota and hydrothermal deposits: present evidence and future experimentation. In: Humphris SE, Zierenberg RA, Mullineaux LS, Thomson RE (eds) Seafloor hydrothermal systems: physical, chemical, biological, and geological interactions. Geophys Monogr Ser 91, American Geophysical Union, Washington, DC, p 178-193
Juniper SK, Tebo BM (1995) Microbe-metal interactions and mineral deposition at hydrothermal vents. In: Karl DM (ed) Microbiology of extreme and unusual environments, Vol 2, Deep-sea hydrothermal vent habitats. CRC Press, New York, p 219-253

Juniper SK, Thompson AJ, Calvert SE (1986) Accumulation of minerals and trace elements in biogenic mucus at hydrothermal vents. Deep-Sea Res 33:401-412

Juniper SK, Tunnicliffe V, Fontaine AR (1988) Biological influences on mineral deposition at deep-sea hydrothermal vents. In: De Luca MP, Babb I (eds) NOAA National Undersea Research Program Report 88-4, Silver Spring, MD, p 99-118

Juniper SK, Tunnicliffe V, Desbruyères D (1990) Regionalscale features of Northeast Pacific, East Pacific Rise, and Gulf of Aden vent communities. In: McMurray GR (ed) Gorda Ridge: a seafloor spreading center in the United States 'Exclusive Economic Zone'. Springer-Verlag, New York, p 265-278

Juniper SK, Jonasson IR, Tunnicliffe V, Southward AJ (1992) Influence of a tube building polychaete on hydrothermal chimney mineralization. Geology (Boulder) 20:895-898

Karl DM (1985) Effects of temperature on the growth and viability of hydrothermal vent microbial communities. In: Jones ML (ed) Hydrothermal vents of the eastern Pacific: an overview. Bull Biol Soc Wash 6:345-353

Karl DM (1995) Ecology of free-living, hydrothermal vent microbial communities. In: Karl DM (ed) Microbiology of extreme and unusual environments, Vol 2, Deep-sea hydrothermal vent habitats. CRC Press, New York, p 35-124

Karl DM, Wirsen CO, Jannasch HW (1980) Deep-sea primary production at the Galapagos hydrothermal vents. Science $207: 1345-1347$

Ketchum (1980) Marine industrial pollution. In: Sears M, Merriman D (eds) Oceanography: the past. Springer-Verlag, New-York, p 397

Koski RA, Jonasson IR, Kadko DC, Smith VK, Wong FL (1994) Compositions, growth mechanisms, and temporal relations of hydrothermal sulfide-sulfate-silica chimneys at the northern Cleft Segment, Juan de Fuca Ridge. J Geophys Res 99(B3):4813-4832

Legendre P, Legendre L (1998) Numerical ecology, 2nd English edn. Elsevier Science BV, Amsterdam

Lilley MD, Butterfield DA, Olson EJ, Lupton JE, Macko SA, McDuff RE (1993) Anomalous $\mathrm{CH}_{4}$ and $\mathrm{NH}_{4}{ }^{+}$concentrations at an unsedimented mid-ocean-ridge hydrothermal system. Nature 364:45-47

Lonsdale P (1977) Clustering of suspension feeding macrobenthos near abyssal hydrothermal vents at oceanic spreading centers. Deep-Sea Res 24:857-863

Martell KA (1997) Population ecology and behaviour dynam. ics of a Buccinid whelk, Buccinum of viridum Dall 1889, from the hydrothermal vent on Juan de Fuca Ridge Northeastern pacific. Hons thesis, Department of Biology, University of Victoria

Martineu P, Juniper SK (1997) Comparison of the benzyl viologen and bimane HPLC assays for the determination of sulfide-oxidizing capability in the tissues of hydrothermal vent and non-vent polychaetes. Can J Zool 75: $1618-1627$

Martineu P, Juniper SK, Fisher CR, Massoth GJ (1997) Sulfide binding in the body fluids of hydrothermal vent Alvinellid polychaetes. Physiol Zool 70(5):578-588

Massoth GJ, Milburn HB, Hammond SR, Butterfield DA, MCDuff RE, Lupton JE (1989) The geochemistry of submarine venting fluids at Axial Volcano, Juan de Fuca Ridge: 
new sampling methods and a VENTS program rationale In: De Luca MP, Babb I (eds) Global venting, midwater, and benthic ecological processes. NOAA National Undersea Research Program Report 88-4, Silver Spring, MD p 29-59

Massoth GJ, Milburn HB, Johnson KS, Coale KH, Stapp MF Meinig C, Baker ET (1991) A SUAVE (Submersible System Used to Assess Vented Emissions) approach to plume sensing: the Buoyant Plume Experiment at Cleft Segment Juan de Fuca Ridge, and plume exploration along the EPR 9-11 $1^{\circ}$ N. EOS Trans Am Geophys Union 72 (44):234

Millero FJ, Sotolongo S, Izaguirre M (1987) The oxidation kinetics of $\mathrm{Fe}$ (II) in seawater. Geochim Cosmochim Acta 51:793-801

Nelson DC, Fisher CR (1995) Chemoautotrophic and methanotrophic endosymbiotic bacteria at deep-sea vents and seeps. In: Karl DM (ed) Microbiology of extreme and unusual environments, Vol 2, Deep-sea hydrothermal vent habitats. CRC Press, New York, p 125-167

Pettibone MH (1988) New species and new records of scaled polychaetes (Polychaeta: Polynoidae) from hydrothermal vents of the northeast Pacific Explorer and Juan de Fuca Ridges. Bull Biol Soc Wash 101:192-208

Oeschger R, Janssen HH (1991) Histological studies on Halicryptus spinulosus (Priapulida) with regard to environmental bydrogen sulfide resistance. Hydrobiologia 222: $1-12$

Robigou V, Delaney JR, Stakes DS (1993) Large massive sulfide deposits in a newly discovered active hydrothermal system, the High-Rise Field, Endeavour Segment, Juan de Fuca Ridge. Geophys Res Lett 20:1887-1890

Sakamoto-Arnold CM, Johnson KS, Beehler CL (1986) Determination of hydrogen sulfide in seawater using flow injection analysis and flow analysis. Limnol Oceanogr $31(4): 894-900$

Sarrazin J, Juniper SK (1998) The use of video imagery to gather biological information at deep-sea hydrothermal vents. Cah Biol Mar 39:255-258

Sarrazin J, Juniper SK (1999) Biological characteristics of a hydrothermal edifice mosaic community. Mar Ecol Prog Ser 185:1-19

Sarrazin J, Juniper SK, Massoth GJ (1993) Using the ROPOS remote vehicle to study biological and physico-chemical zonation on hydrothermal chimneys. EOS Trans Am Geophys Union 74(43):560

Sarrazin J, Robigou V, Juniper SK, Delaney JR (1997) Biological and geological dynamics over four years on a high temperature sulfide structure at the Juan de Fuca Ridge hydrothermal observatory. Mar Ecol Prog Ser 153:5-24

Schultz A, Delaney JR, McDuff RE (1992) On the partitioning of heat flux between diffuse and point source seafloor venting. J Geophys Res 97:12229-12314

Segonzac M, de Saint-Laurent M. Casanova B (1993) L'énigme du comportement trophique des crevettes Alvinocarididae des sites hydrothermaux de la dorsale médioatlantique. Cah Biol Mar 34:535-571

Somero GN, Childress JJ, Anderson AE (1989) Transport, metabolism and detoxification of hydrogen sulfide in animals from sulfide rich marine environments. Rev Aquat Sci 1:591-614

Sousa WP (1984) The role of disturbance in natural communities. Annu Rev Ecol Syst 15:353-391

Southward EC, Tunnicliffe V, Black MB, Dixon D, Dixon L (1997) Ocean ridge segmentation and vent tubeworms (Vestimentifera) in the NE Pacific. In: MacLeod CJ, Tyler $\mathrm{P}$, Walker CL (eds) Tectonic, magmatic, hydrothermal and biological segmentation of mid-ocean ridges, Vol 118.
Geological Society of London, Special. Publication, London, p 211-224

ter Braak CJF (1986) Canonical correspondence analysis: a new eigenvector technique for multivariate direct gradient analysis. Ecology 67:1167-1179

ter Braak CJF (1987a) The analysis of vegetation-environment relationships by canonical correspondence analysis. Vegetatio 69:69-77

ter Braak CJF (1987b) Ordination. In: Jongman RHG, ter Braak CJF, Van Tongeren OFR (eds) Data analysis in community and landscape ecology, Chap 5. Pudoc, Wageningen, p 91-173

ter Braak CJF (1988) Canoco-an extension of Decorana to analyze species-environment relationships. Vegetatio 75 : $159-160$

ter Braak CJF (1990) Update notes: Canoco version 3.10 Agricultural Mathematics Group, Pudoc, Wageningen

Thomson RE, Delaney JR, McDuff RE, Janecky DR, McClain JS (1992) Physical characteristics of the Endeavour Ridge hydrothermal plume during July 1988. Earth Planet Sci Lett 111:141-154

Tivey MK (1995) Modeling chimney growth and associated fluid flow at seafloor hydrothermal vent sites. In: Humphris SE, Zierenberg RA, Mullineaux LS, Thomson RE (eds) Seafloor hydrothermal systems: physical, chemical, biological, and geological interactions. Geophys Monogr Ser 91. American Geophysical Union. Washington, DC. p 158-177

Tivey MK, Delaney JR (1986) Growth of large sulfide structures on the Endeavour segment of the Juan de Fuca Ridge. Earth Planet Sci Lett 77:303-317

Tunnicliffe $V$ (1991) The biology of hydrothermal vents: ecology and evolution. Oceanogr Mar Biol Annu Rev 29: $319-407$

Tunnicliffe V. Fontaine AR (1987) Faunal composition and organic surface encrustations at hydrothermal vents on the southern Juan de Fuca Ridge. J Geophys Res 92(B11): $11303-11314$

Tunnicliffe V, Jensen GR (1987) Distribution and behaviour of the spider crab Macroregonia macrochira Sakai (Brachyura) around the hydrothermal vents of the northeast Pacific. Can J Zool 65:2443-2449

Tunnicliffe V. Juniper SK (1990) Dynamic character of the hydrothermal vent habitat and the nature of sulphide chimney fauna. Prog Oceanogr 24:1-13

Tunnicliffe V, Juniper SK, de Burgh ME (1985) The hydrothermal vent community on Axial Seamount, Juan de Fuca Ridge. Bull Biol Soc Wash 6:453-464

Tunnicliffe $V$, Botros $M$, de Burgh ME, Dinet A, Johnson HP, Juniper SK, McDuff RE (1986) Hydrothermal vents of Explorer Ridge, northeast Pacific. Deep-Sea Res 33: $401-412$

Tunnicliffe V, Garrett JF, Johnson HP (1990) Physical and biological factors affecting the behavior and mortality of hydrothermal vent tubeworms (vestimentiferans). DeepSea Res 37(1):103-125

Tunnicliffe V, Desbruyères D, Jollivet D, Laubier L (1993) Systematic and ecological characteristics of Paralvinella sulfincola Desbruyères and Laubier, a new polychaete (family Alvinellidae) from northeast Pacific hydrothermal vents. Can J Zool 71:286-297

Tunnicliffe V, Embley RW, Holden JF, Butterfield DA, Massoth G, Juniper SK (1997) Biological colonization of new hydrothermal vents following an eruption on Juan de Fuca Ridge. Deep-Sea Res 44:1627-1644

van Dover CL (1995) Ecology of mid-Atlantic ridge hydrothermal vents. In: Parson LM, Walker CL, Dixon 
DR (eds) Hydrothermal vents and processes, Vol 87 Geological Society of London, Special Publication, London, p 257-294

von Damm KL (1995) Controls on the chemistry and temporal variability of seafloor hydrothermal fluids. In: Humphris SE, Zierenberg RA, Mullineaux LS, Thomson RE (eds) Seafloor hydrothermal systems: physical, chemical, biological, and geological interactions. Geophys Monogr Ser 91, American Geophysical Union, Washington, DC, p 222-227

Witman JD, Cooper RA (1983) Disturbance and contrasting

Editorial responsibility: Otto Kinne (Editor),

Oldendorf/Luhe, Germany patterns of population structure in the brachiopod Terebratulina septentrionalis (Couthouy) from two subtidal habitats. J Exp Mar Biol Ecol 73:57-79

Witman JD, Sebens KP (1988) Benthic community structure at a subtidal rock pinnacle in the central Gulf of Maine. In: Babb I, De Luca M (eds) Benthic productivity and marine resources of the Gulf of Maine. Natl Undersea Res Prog, Res Report 88-3, Rockville, MD

Wootton JT (1993) Indirect effects and habitat use in an intertidal community: interaction chains and interaction modifications. Am Nat 141:71-89

Submitted: February 17, 1999; Accepted: June 10, 1999

Proofs received from author(s): November 26, 1999 